\title{
Denmark: 2008 Article IV Consultation-Staff Report; Staff Statement; Public Information Notice on the Executive Board Discussion; and Statement by the Executive Director for Denmark
}

Under Article IV of the IMF's Articles of Agreement, the IMF holds bilateral discussions with members, usually every year. In the context of the 2008 Article IV consultation with Denmark, the following documents have been released and are included in this package:

- $\quad$ The staff report for the 2008 Article IV consultation, prepared by a staff team of the IMF, following discussions that ended on October 2, 2008, with the officials of Denmark on economic developments and policies. Based on information available at the time of these discussions, the staff report was completed on November 26, 2008. The views expressed in the staff report are those of the staff team and do not necessarily reflect the views of the Executive Board of the IMF.

- A staff statement of December 19, 2008, updating information on recent developments.

- $\quad$ A Public Information Notice (PIN) summarizing the views of the Executive Board as expressed during its December 19, 2008 discussion of the staff report that concluded the Article IV consultation.

- $\quad$ A statement by the Executive Director for Denmark.

The document listed below has been separately released.

Selected Issues Paper

The policy of publication of staff reports and other documents allows for the deletion of market-sensitive information.

\footnotetext{
Copies of this report are available to the public from

International Monetary Fund $\bullet$ Publication Services

$70019^{\text {th }}$ Street, N.W. $\bullet$ Washington, D.C. 20431

Telephone: (202) 623-7430 • Telefax: (202) 623-7201

E-mail: publications@imf.org • Internet: http://www.imf.org
}

Price: $\$ 18.00$ a copy

\section{International Monetary Fund Washington, D.C.}



INTERNATIONAL MONETARY FUND

DENMARK

\title{
Staff Report for the 2008 Article IV Consultation
}

\author{
Prepared by the European Department
}

Approved by Peter Doyle and Martin Mühleisen

November 26, 2008

\section{Executive Summary}

Background. The global liquidity crisis put the financial sector under severe stress but most banks have weathered the crisis well owing to strong initial positions and supportive policies. The crisis accelerated a downturn that had begun in 2007—after a two-year boom — and tilted the balance of macroeconomic risk towards recession. Inflation, which picked up in 2007, has started to slow but the output gap is still high and unemployment is still near a 30-year low, resulting in still-fast wage growth. The boom swelled Denmark's fiscal surpluses, reducing the government debt burden.

Outlook. Economic growth will drop below potential in 2008, and the output gap is expected to turn negative in 2009. Recovery is expected to begin in 2010.

Staff's views. The authorities' response to the crisis has been bold and well conceived. Special liquidity measures and a public-private Financial Stability Agreement (which includes a broad guarantee of liabilities) are ensuring access to liquidity and should bolster creditor confidence. The macroeconomic policy mix is appropriate - higher interest rates to support the exchange rate peg and an expansionary budget to add a countercyclical thrust to the strong stabilizing effect of Denmark's automatic stabilizers. At this point, the case for further discretionary easing is weak because some slowing is needed to stop the decline in competitiveness and automatic stabilizers will cushion the impact of a faster-thananticipated slowdown. Regarding fiscal sustainability, the impressive fiscal reforms of the last few years have gone a long way towards closing the long term fiscal gap, but further action is needed to offset more recent tax cuts and spending commitments.

Authorities' position. Given the slippage in wage competitiveness and the still strong cyclical position the authorities were wary of fiscal expansion, preferring to rely on automatic stabilizers rather than discretionary policies. They are strongly committed to Denmark's rule-driven policy framework, anchored by the exchange rate peg and a medium term fiscal framework. Looking ahead, closing the long-term fiscal gap is a key priority but the authorities consider it difficult to make further progress so soon after the major reforms in 2006.

The discussions. A mission comprising Franek Rozwadowski (Head), Jay Surti, Allan Brunner, and Mali Chivakul (EUR) visited Copenhagen on September 22-October 2, 2008. The mission met with the Minister of Finance; the Chairman of the Board of Governors of Danmarks Nationalbanken; the Deputy Director General of the Danish Financial Supervisory Authority; the Deputy Permanent Secretary, Ministry of Business and Economic Affairs; and other senior officials. The mission also met parliamentarians, representatives of trade unions and business associations, and financial institutions. 


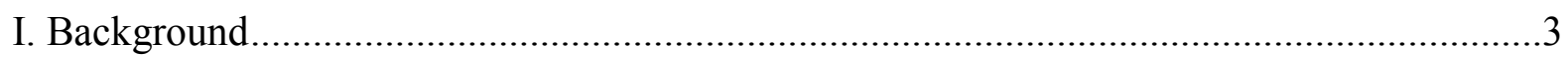

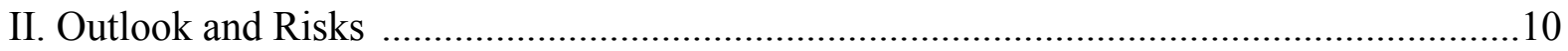

III. Policies And Discussions ..................................................................................... 12

A. Containing the Impact of the Global Financial Crisis......................................... 12

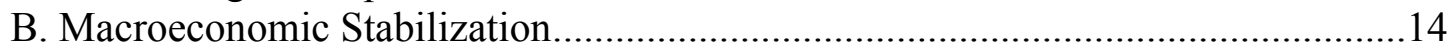

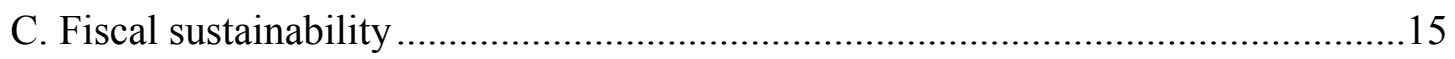

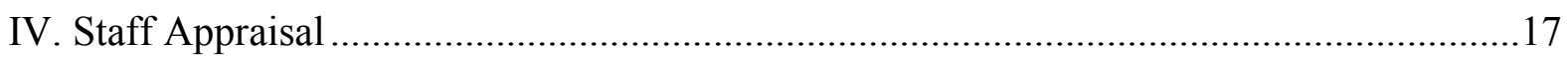

Figures

1. The Downswing Gathers Pace ....................................................................................4

2. Capacity Constraints, Costs, and Price, 2000-present.................................................

3. Competitiveness Under Strain ............................................................................. 7

4. Developments in the Financial Sector .........................................................................

5. Fiscal Developments in a European Perspective ......................................................

Tables

1. Selected Economic an Social Indicators, 2000-08 .......................................................20

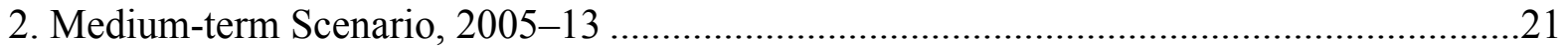

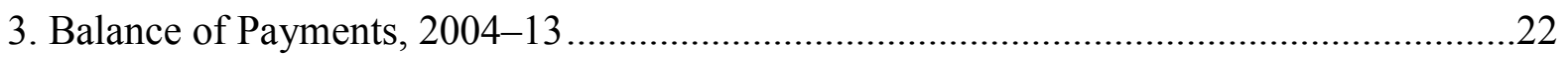

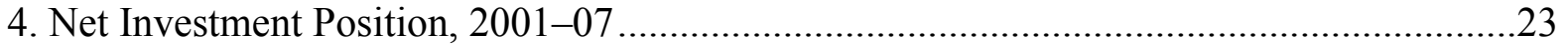

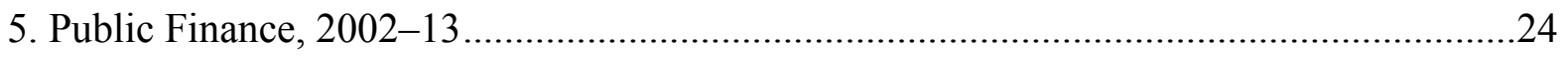

6. Indicators of External and Financial Vulnerability, 2002-08.......................................25

7. Financial Soundness Indicators of Major Danish Banks ...........................................26

\section{Boxes}

1. Implementation of Fund Policy Advice ............................................................................

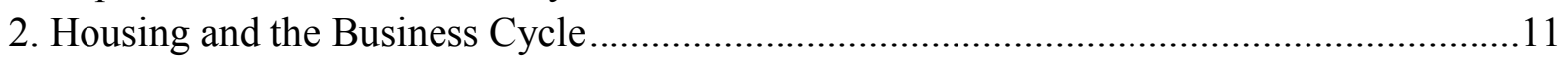

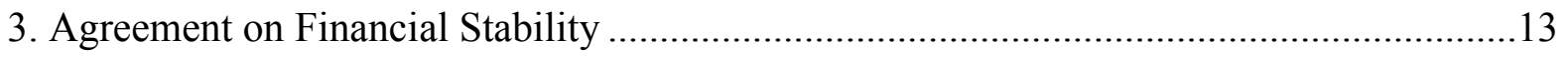




\section{BACKGROUND}

1. In Denmark, the global financial turbulence which gathered force in $\mathbf{2 0 0 8}$ added fuel to a cyclical slowdown that had begun in early 2007. From the perspective of macroeconomic management, the timing of the crisis was fortuitous since the cyclical position was still strong and a slowdown was called for. From the perspective of financial stability, however, the timing was inopportune: banks with exposures to the slumping construction sector were writing down loans just when the crisis raised their funding cost and froze their foreign funding lines. Through the crisis, the authorities adhered to their macroeconomic policy framework - a euro peg and fiscal rules which allow full play to automatic stabilizers - while moving decisively to ensure banking system liquidity and reassure creditors. This report was written in the midst of the crisis. The policy discussions were held in late September, but the report also covers developments and policy responses through early November.

\section{Box 1. Implementation of Fund Policy Advice}

Denmark's policies are generally consistent with Executive Board views. Recent policy changes have been in line with some but not all the recommendations made in the 2006 Article IV consultation: the marginal tax rate on labor income is being cut, but the authorities have ruled out financing the cut by raising property taxes. Consistent with the 2006 Financial Sector Assessment Program (FSAP) recommendation, more resources have recently been announced for the financial system supervisor (DFSA) in order to facilitate more intensive risk-based supervision.

2. The slowdown began with a reversal of the factors that had fueled the 2005-07 upswing (Figure 1). The housing boom ended when mounting supply pricked the price bubble and slowed construction; ebullient consumer confidence wilted in the face of falling home values; and previously easy lending conditions tightened as interest rates rose and defaults on construction loans increased. Residential and business fixed investments declined and export growth decelerated. By late 2008 the slowdown was firmly in place but the output gap was still high and the labor market was still overheated (Figure 2).

3. The labor market responded to both upswing and downturn with a lag. Early in the boom, labor supply was expanded by structural reforms and an influx of workers from EU new member states. Consequently, the upswing had an unusually large impact on employment and an unusually small impact on wages. In mid-2007, however, wage growth finally picked up; it has remained strong despite slowing output growth, although the most recent data show some moderation. The tight labor market, a generous 2008 public sector wage agreement, and rising food and fuel prices have pushed nominal wage growth to about 4.5 percent, implying real wage growth in excess of productivity growth. The downward 
march of the unemployment rate ended in August but unemployment remains at a record low, well below the estimated NAIRU, and vacancy rates are high. ${ }^{1}$

Figure 1. Denmark: the downswing gathers pace

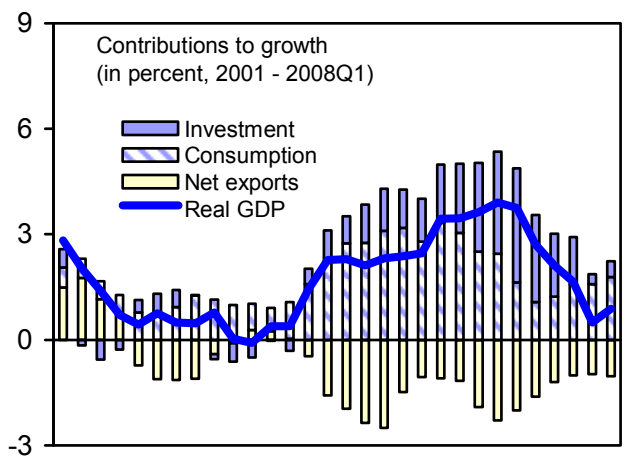

20012002200320042005200620072008
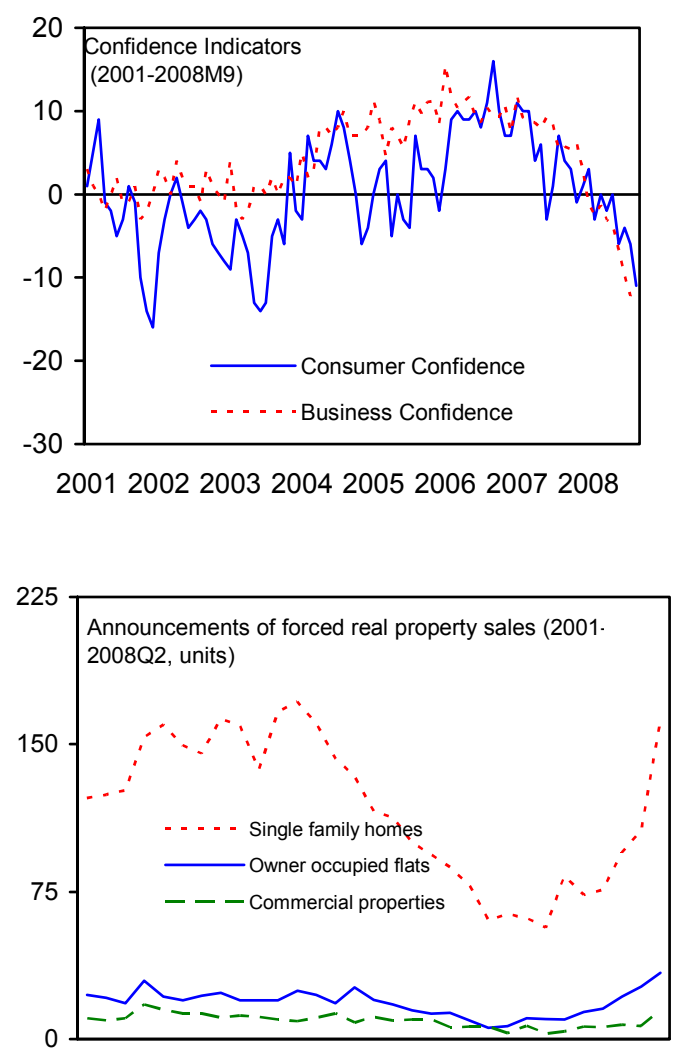

20012002200320042005200620072008
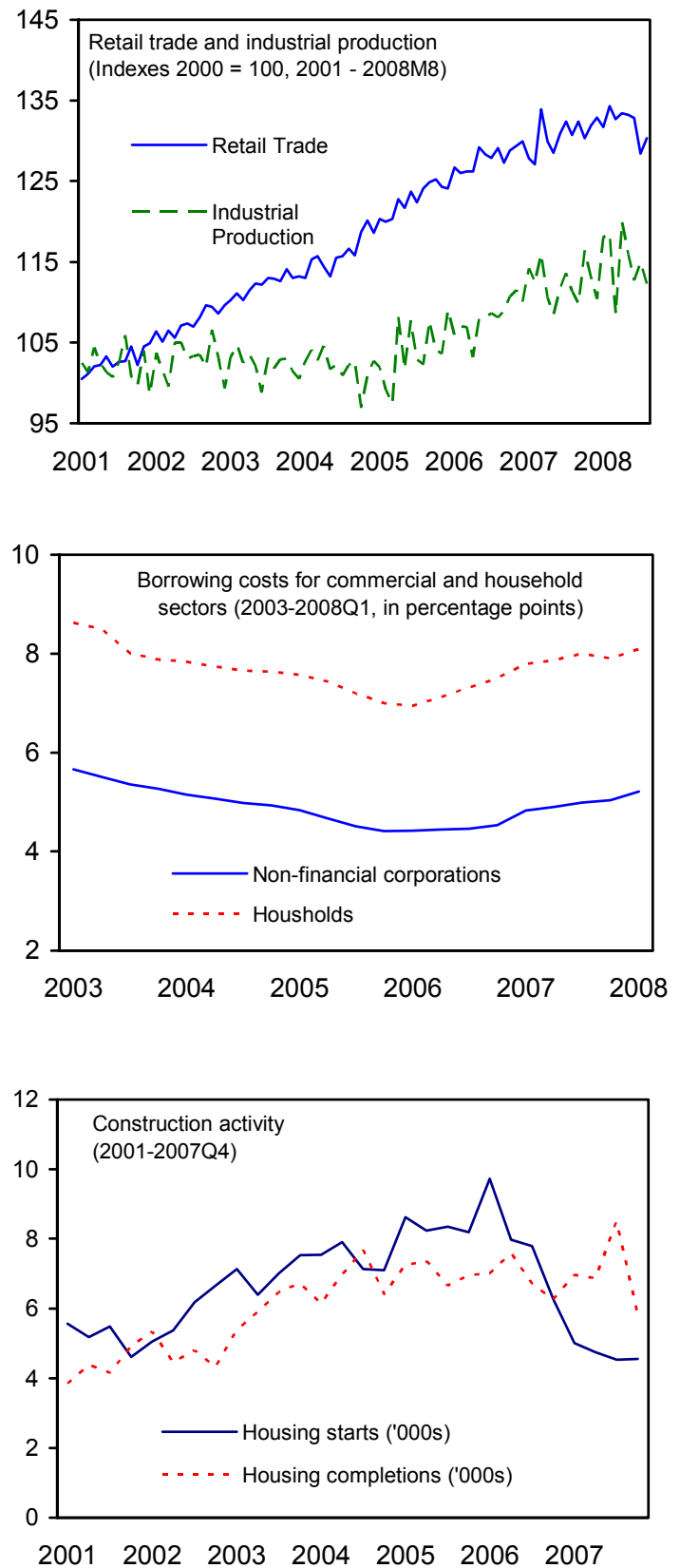

Sources: Statistics Denmark and staff calculations

${ }^{1}$ See the Selected Issues paper "Labor market reforms, changing demographics, and the Danish NAIRU" by Jay Surti. 
Figure 2. Denmark: capacity constraints, costs, and prices, 2000-present
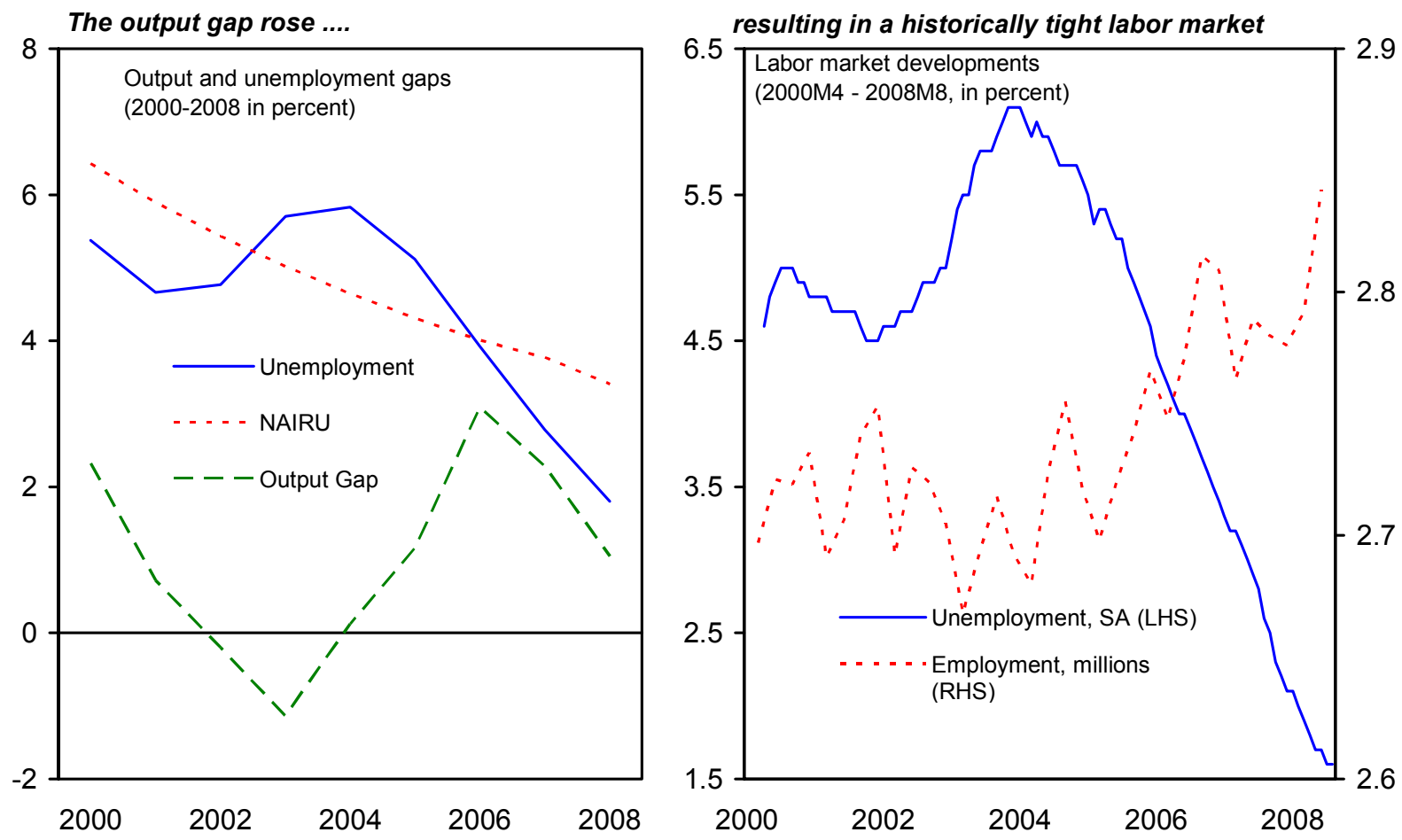

Wage growth exceeded productivity gains ...
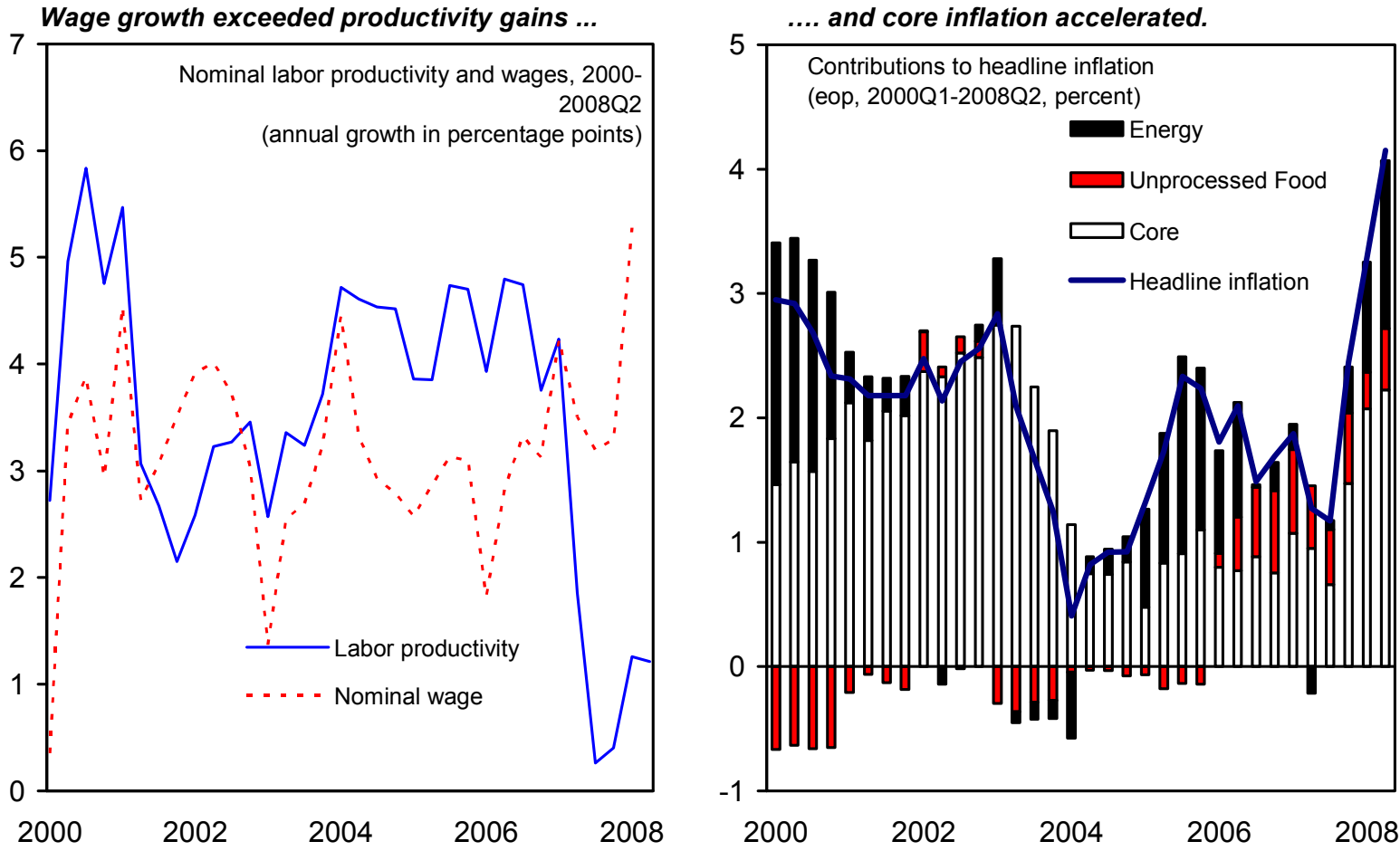

Sources: Eurostat, Statistics Denmark, and staff calculations 
4. Like wages, prices were quiescent during the first two years of the upswing and picked up only in late 2007. Inflation, kept low by wage moderation and favorable import prices, dipped below the eurozone level even as demand took off. But it accelerated to just under 5 percent in 2008, pushed up by food and energy prices and an increase in core inflation following the wage acceleration. Inflation expectations worsened starting in mid2007, though they have since stabilized with the downturn in commodity prices and the global outlook.

\section{Competitiveness is adequate, but trends in wages and productivity are}

unsustainable. CGER analysis suggests that the real effective exchange rate (REER) is well aligned - the three approaches show an average overvaluation of less than 2 percent (Text table). But wage competitiveness has been eroded by slower productivity growth and faster real wage growth than in trading partners (Figure 3). To date, the impact on the REER has been softened by structural shiftsa move towards higher-value added goods

CGER Estimates of REER Misalignment 1/

\begin{tabular}{lccc}
\multicolumn{4}{c}{ (in percent) } \\
\hline & MB & ERER & ES \\
\hline Denmark & -1 & +4 & +2 \\
Euro area & +5 & +20 & +4 \\
Sweden & 0 & -13 & -14 \\
\hline 1/MB: macrobalance; ERER: equilibrium real exchange rate; ES: external stability
\end{tabular}
(sustaining profitability) and an improvement in the terms of trade (making real wages rise faster than product wages). Even so, the REER is high relative to recent norms, the external current account surplus has been narrowing, and Denmark's share in global export markets has declined.

\section{The global crisis has put financial markets under strain but most banks,} including the half dozen largest, have weathered it well. This reflects conservative investment strategies in a sound regulatory environment. Although mortgage lending has grown rapidly in recent years, against the background of a housing boom, credit risk management standards are high and market risk is limited because most funding is through covered bonds. Large commercial banks - accounting for about 80 percent of assets - and specialized mortgage banks are well-capitalized. But small and medium sized banks-which grew rapidly in recent years - have slim excess capital buffers (Table 7). Direct effects of the global crisis were small because exposure to U.S. subprime assets was limited and subsidiaries of foreign banks were subject to tight restrictions on intra-group exposures. Spillover risk from subsidiaries in the Baltics and Ireland was very small since they represented only about 5 percent of the parent bank's credit portfolio and 2 percent of group profits. Instead, the main channels of contagion were increasing risk aversion and the dryingup of liquidity (Figure 4). Hardest hit were small and medium sized banks, which had increased their reliance on money market funding that now became difficult — and costly - to roll over. This gave rise to a clutch of mergers and takeovers, including a high profile central bank intervention in a midsize bank with an exceptionally weak loan portfolio. Fortunately, most banks entered the crisis with healthy capital buffers (Table 6), partly because the reduction of capital requirements under Basel II was phased in gradually. 
Figure 3. Denmark: Competitiveness Under Strain
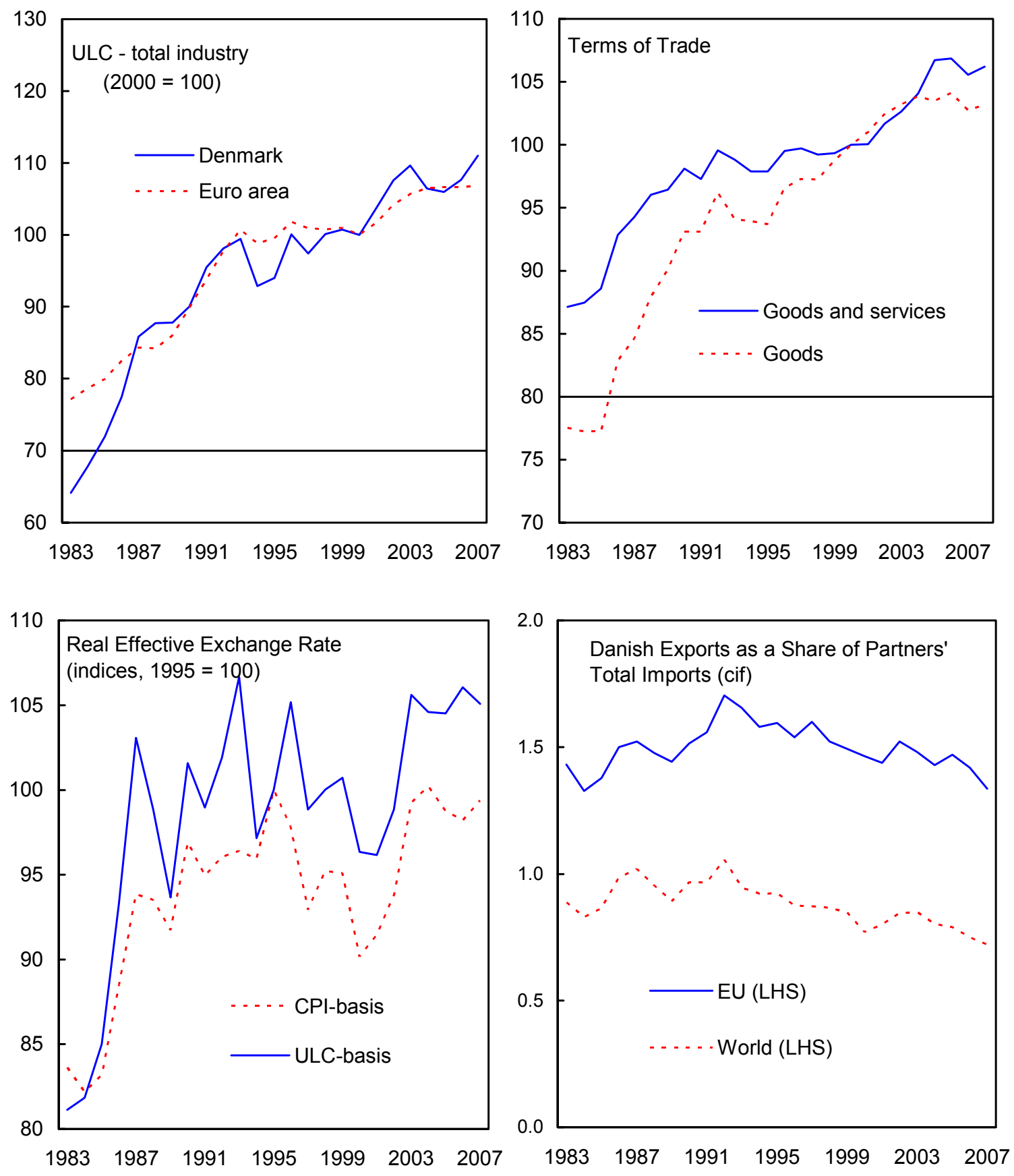

Sources: CGER, Direction of Trade Statistics, IFS, and World Economic Outlook. 
Figure 4. Denmark: Developments in the Financial Sector
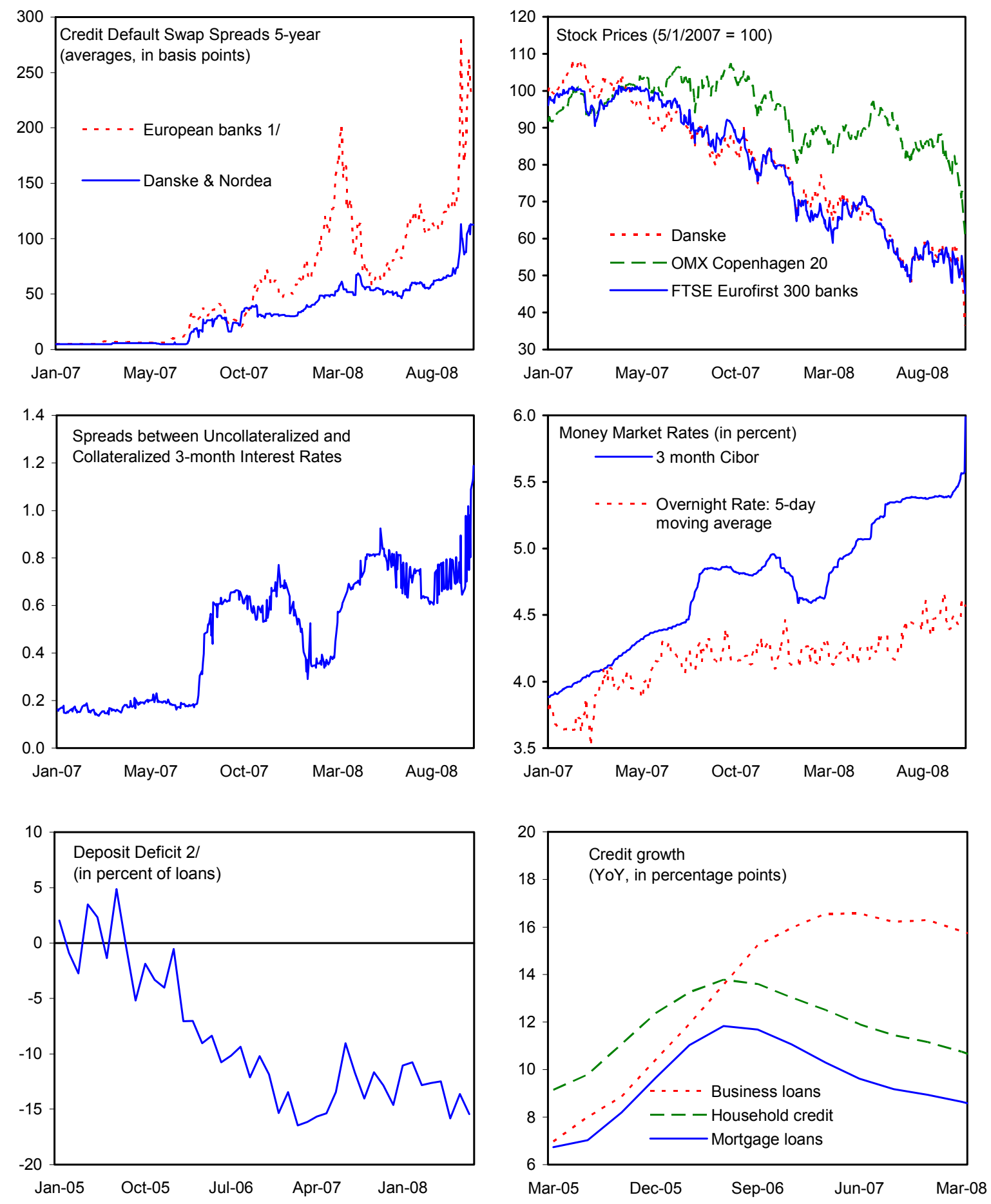

Sources: Bloomberg, Danmarks Nationalbank, and Statistics Denmark.

1/ Average of RBS, HBOS, HSBC, UBS and Barclays.

2/ Difference between Non-MFI deposits and loans. 


\section{Denmark's fiscal position is among the strongest in the EU (Figure 5). The}

expenditure ratio came down considerably during the last decade, though it is still high, reflecting the cost of the welfare state. With taxes even higher, the general government surplus is among the largest in the EU.

Consequently, the debt ratio has declined to a little over 20 percent and interest rate spreads on government debt are negligible (though they have been pushed up by the financial crisis). The $4 \frac{1}{2}$ percentage point increase in the fiscal surplus since 2003 (Table 1, Text Chart) stemmed from cyclical factors - strong employment and reduced unemployment —as well as structural factors - rising North Sea oil and gas activities and lower net interest payments.
Denmark: strengthening fiscal performance, 2002-07 1/

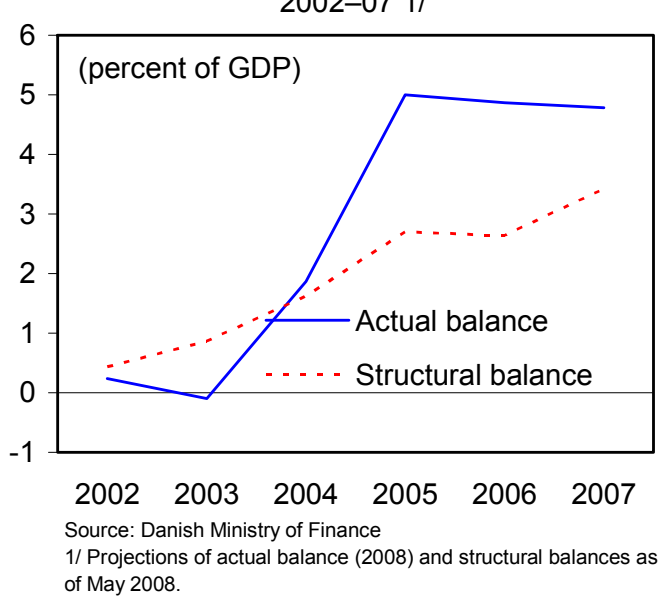

Figure 5. Denmark: Fiscal Developments in a European Perspective
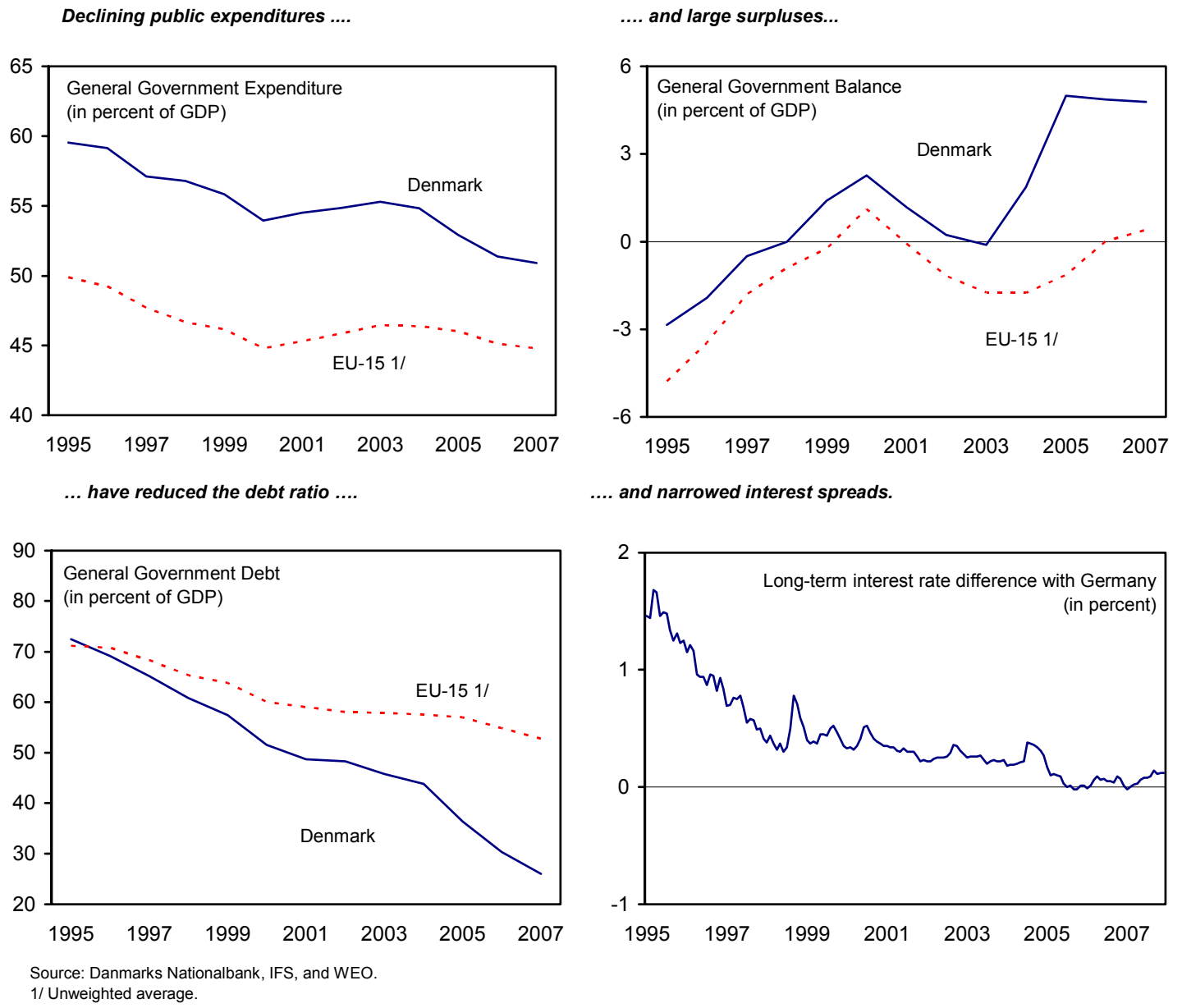

.... and narrowed interest spreads.

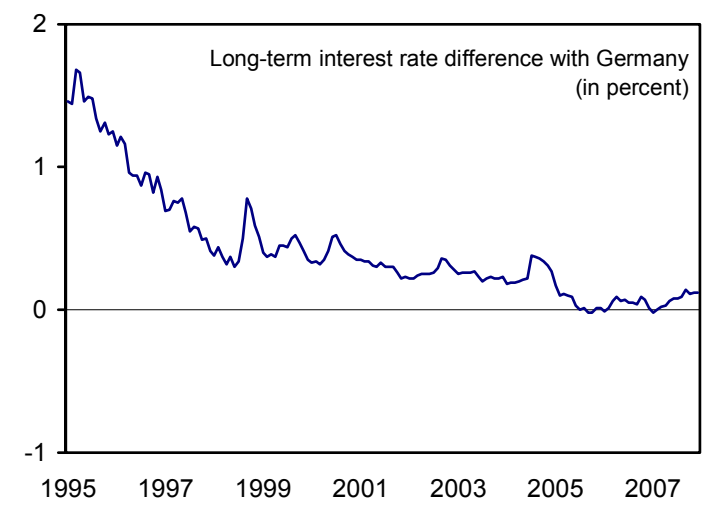

Source: Danmarks Nationalbank, IFS, and WEO.

1/Unweighted average. 


\section{OUTLOOK AND RISKS ${ }^{2}$}

8. The global financial crisis and downturn are clouding the outlook. Growth is expected to be weak through 2010 before reverting gradually to potential (Table 2, text table). On the domestic front, borrowing costs have risen and confidence has been shaken by falling home values, rising corporate defaults, and banking problems. Recent survey data indicate a downward slide in expectations of economic performance over the next 12 months; this should be reflected in sluggish consumption and weak investment. On the external front, export growth will be pulled down by slower growth in key export markets: Germany, Sweden, the United Kingdom, and the United States. But, assuming the global economy revives in late 2009, growth should remain in positive territory. In the near term, the slowdown in consumption will be cushioned by still high employment, rising real wages and fiscal automatic stabilizers. Over time, rising unemployment and weaker inflationary expectations should reduce wage pressures, enabling firms to rebuild profit margins and creating conditions for a pick-up in growth.

\begin{tabular}{|c|c|c|c|c|c|c|c|}
\hline \multicolumn{8}{|c|}{$\begin{array}{c}\text { Denmark: Medium-term Outlook } \\
\text { (Percentage change, unless otherwise indicated) }\end{array}$} \\
\hline & 2007 & 2008 & 2009 & 2010 & 2011 & 2012 & 2013 \\
\hline Real GDP & 1.7 & 0.6 & 0.3 & 0.4 & 1.1 & 1.6 & 1.6 \\
\hline Real domestic demand & 3.1 & 1.6 & -0.2 & 0.3 & 1.1 & 1.9 & 1.9 \\
\hline Net exports 1/ & -1.0 & -0.4 & 0.4 & 0.2 & 0.0 & -0.3 & -0.3 \\
\hline Exports & 1.9 & 1.9 & 1.0 & 3.3 & 2.0 & 3.3 & 3.3 \\
\hline Imports & 3.8 & 2.6 & 0.2 & 3.0 & 2.0 & 3.8 & 3.8 \\
\hline Current account $2 /$ & 1.1 & 0.9 & 0.5 & 0.8 & 0.8 & 0.6 & 0.4 \\
\hline \multicolumn{8}{|l|}{ Inflation } \\
\hline Consumer Prices & 1.7 & 3.4 & 2.3 & 2.1 & 1.9 & 1.9 & 1.9 \\
\hline \multicolumn{8}{|l|}{ Labor market } \\
\hline Average unemployment rate & 2.8 & 1.8 & 3.0 & 3.7 & 4.0 & 4.0 & 4.0 \\
\hline Output gap 3/ & 2.3 & 1.0 & -0.1 & -0.7 & -0.3 & -0.1 & 0.0 \\
\hline
\end{tabular}

9. Considerable downside risk attends this central outlook. A more prolonged global recession could constrain export growth through 2010. Moreover, it may be difficult to reduce interest rates in the context of a flight to liquidity in global currency markets. In the immediate future, tight liquidity could push up interest rates on adjustable rate mortgages that will reset in December - which amount to 13 percent of GDP. Higher interest costs - just as

\footnotetext{
${ }^{2}$ The near-term outlook has deteriorated since the discussions. Growth projections for 2008-10 have been revised downward by 0.2-0.4 percentage points since September and the output gap, which was projected to gradually decline towards zero is now projected to be negative in 2009-12.
} 
unemployment starts rising - could lead to household belt-tightening, a spike in mortgage defaults, a further decrease in home values, and second-round effects on investment and employment (Box 2). This could pull the economy into a recession.

\section{Box 2. Housing and the Business Cycle}

House prices overshot fundamentals during the recent boom and have yet to correct fully. ${ }^{3}$ In these circumstances an increase in interest rates on adjustable rate mortgages combined with a rise in unemployment could trigger an abrupt adjustment. This would depress construction, drive up unemployment, and weaken the performance of real estate-related loan portfolios.

\section{WEO estimates suggest that Danish housing prices were about 20 percent overvalued in}

December 2007 (text chart). Since then, prices have decreased only 2 percent, leaving them well above the level justified by fundamentals such as disposable income and construction cost.

\section{A drop in house prices would raise unemployment significantly due to a large impact on} construction. House prices have been highly correlated with residential construction; the high labor intensity of construction implies a correspondingly high impact on employment.

The impact on consumption could also be large. While the correlation between consumption and home values has been low in the past, the impact could be large when compounded by high interest costs, a collapse in share prices and rising unemployment.

The ultimate impact-magnified by a "financial accelerator"-could be protracted low growth and high unemployment. Foreclosures resulting from high interest rates on variable-rate mortgages could depress home values and undermine recovery on defaulted mortgages. Banks would make losses when balance-sheets were already damaged by rising unemployment, falling household wealth and weaker corporate balance-sheets. This could result in a longer period of tight credit and higher borrowing costs, delaying economic recovery.
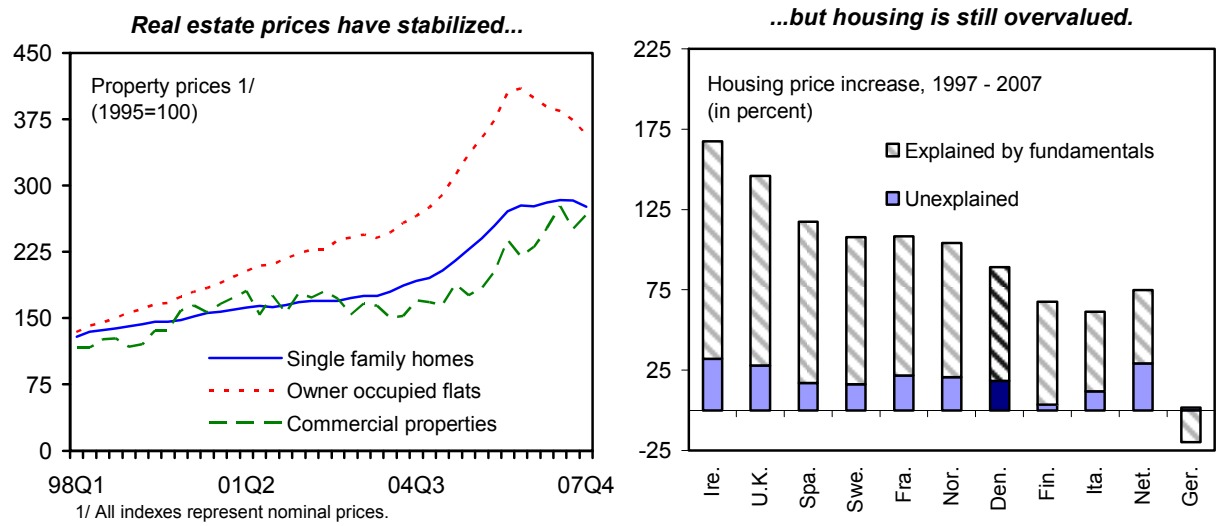

${ }^{3}$ See International Monetary Fund (2008) World Economic Outlook, April, Chapter 3. 
10. Wage growth is a concern but appears to be moderating. As noted, rising wages are contributing to an erosion of competitiveness. Looking forward, however, rising unemployment, falling vacancy rates, and a trend towards more decentralized wage setting in the private sector should help break wage momentum.

\section{Policies And Discussions}

\section{Faced with the global financial crisis, the authorities have taken steps to secure} the twin anchors of their policy framework-the euro peg and fiscal automatic stabilizers. The peg stabilizes inflation by importing the ECB's monetary stance. The authorities have reaffirmed their commitment to it and taken the steps needed-including interest rate hikes - to support foreign exchange reserves and maintain euro liquidity. Denmark's fiscal rules have two objectives: long-term sustainability - achieved through a target range for the structural balance - and demand management - achieved via automatic stabilizers. Despite the possibly severe downturn the authorities plan to stick to this framework - relying on automatic stabilizers to cushion the slowing in demand without a discretionary fiscal impulse. Moreover, they have reduced the likelihood of a severe downturn with measures that should keep financial markets functioning and liquidity flowing.

\section{A. Containing the Impact of the Global Financial Crisis}

12. The response to the global crisis has been timely and comprehensive. The key objective has been to support confidence; the key measures have aimed to maintain liquidity and ensure that banks can honor all unsubordinated claims even if they come under stress.

13. Early efforts to alleviate liquidity shortages in the banks had mixed success, and were followed by more direct interventions. An attempt in May to revive the interbank market by introducing loan bills — usable as collateral at Danmarks Nationalbanken (DNB) was not successful because it failed to address banks' strong liquidity preference and aversion to counterparty risk. With small and medium sized banks frozen out of the money market, the DNB ratcheted up its response in September by broadening the set of collateral it accepts and creating a framework for uncollateralized lending to banks with excess capital. In October, in another attempt to revive the interbank market, a state guarantee was extended to interbank lending. Finally, banks' need to service clients requesting dollar liquidity was met by a government issue of T-bills (which the US Federal Reserve accepts as collateral) and a central bank auction of funds obtained via a swap line with the Federal Reserve.

14. Foreign exchange market pressures in October have pushed up the interest rate. The market's flight to liquidity included a shift out of krone into the deeper euro market, leading to reserve outflows. The authorities, whose monetary policy is focused tightly on sustaining the peg, responded by increasing domestic interest rates (now 175 bps higher than the euro rate), buttressing reserves with the proceeds of euro-denominated government borrowing, and arranging a currency swap with the ECB. The interest rate hike stemmed the 
outflow but it could push up mortgage financing costs when adjustable rates are reset in December. The episode has revived discussions of a new referendum on euro adoption, possibly in 2011 .

\section{In October, as the financial crisis deepened, the government and the banking} sector agreed on an innovative and comprehensive framework to enhance financial stability (Box 3). The overriding objective was to build confidence. The framework embeds features aimed at normalizing the interbank market and avoiding disruptive suspensions of payments, It secures the financial participation of the private sector through a Private Contingency Association (PCA). It provides an incentive for distressed banks to seek preemptive private-sector solutions since shareholders of a bank wound up under the terms of the new Act lose control of it. It also promotes the consolidation of the sector by easing financial constraints that could block takeovers of distressed banks. Finally, eligibility requirements are designed to reduce domestic and cross country "beggar thy neighbor" effects. The framework has not yet been used, but some of its features - including financial participation by the PCA — were present in the resolution of Roskilde bank in July-August.

\section{Box 3. Agreement on Financial Stability}

Key features of the agreement include a blanket guarantee and procedures for the orderly winding up of distressed banks. Parts of the framework are entrenched in a Financial Stability Act, that has the following key elements:

Guarantee of claims. All deposits and other unsecured claims on banks belonging to the PCA are guaranteed. 133 banks - and 99 percent of deposits - are covered.

Winding up company (WUC). Banks whose capital falls below the regulatory floor must allow a stateowned WUC to arrange for purchase or wind-up. All deposits and unsecured claims are honored but shareholders lose control of the bank.

Burden sharing. The PCA is set up as an insurance scheme. Member banks pay premia and make guarantees that, together, cover the first DKK 35 billion of losses incurred by the WUC (equivalent to 2 percent of GDP). Beyond that, losses are covered by the state, which also receives any profit earned by the WUC.

Level playing field. The guarantee covers all PCA member banks. It can cover branches abroad only if the host country has a similar guarantee. The Act also extends the coverage of the regular Deposit Guarantee Fund to Danish branches of foreign banks.

Addressing moral hazard and intensifying supervision. The Act has a framework for expelling a bank that takes on greater risk under the umbrella of the guarantee. Alternatively the DFSA may dismiss members of the board of directors or order the bank to dismiss a member of its management board.

Another key element of the agreement was an undertaking by participating banks not to pay dividends, create new redemption programs or initiate new share purchases. 
16. Staff raised concern about the adequacy of the DFSA's resources. The economic slowdown and continued pressure in global financial markets call for intensified monitoring of the financial sector. The transition to Basel II has expanded the DFSA's supervisory mandate, and the mission - following-up on the 2006 FSAP - emphasized the need for resources to recruit and retain risk experts necessary to fulfill this mandate. The mission also pointed out that the difficulties of small banks during the downturn underscored the need to supervise them more frequently. The authorities increased the DFSA's resources as part of the political agreement on financial stability.

17. The authorities emphasized that the introduction of the mortgage covered bond legislation in 2007 strengthens lenders' risk management practices. The legislation tightens loan-to-value standards and provides incentives for commercial banks to strengthen market risk management by aligning securitization techniques more closely with the "balance principles" used by mortgage banks.

\section{B. Macroeconomic Stabilization}

\section{Denmark's macroeconomic framework relies to a large degree on automatic} stabilizers. The peg rules out discretionary monetary policy since monetary conditions are determined by the exigencies of sustaining the peg (text chart). Under the current exceptional circumstances, this has meant raising krone interest rates despite a decline in euro rates. Discretionary fiscal policy is also tightly constrained-by fiscal rules enshrined in political agreements, by large expenditure entitlements, and by multi-year wage contracts. Denmark's fiscal automatic stabilizers are among the strongest in Europe (text table) — reflecting high marginal tax rates and a social safety net that kicks in when unemployment rises.

19. Within this framework the authorities are planning a gradual decline in the structural surplus over the next six years - a sustained moderate fiscal expansion. In part the decline reflects exogenous secular changes: a demographic shift is pushing up age-related expenditures

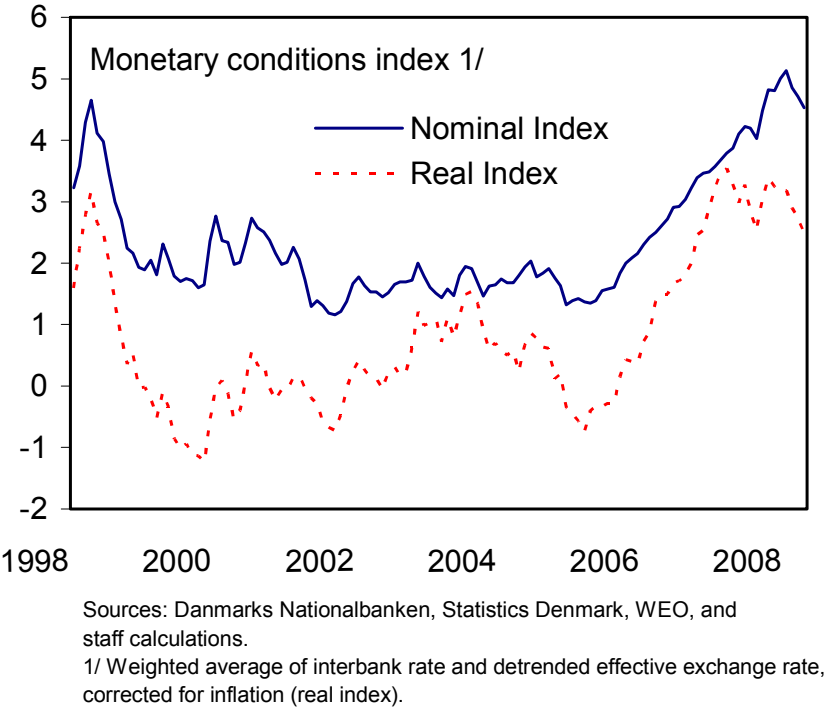

Budgetary impact of a 1 percent change in GDP (in percent of GDP)

\begin{tabular}{llll}
\hline Denmark & $\mathbf{0 . 8 5}$ & Italy & 0.48 \\
Sweden & 0.79 & France & 0.46 \\
Netherlands & 0.76 & Greece & 0.42 \\
Belgium & 0.67 & Spain & 0.40 \\
Finland & 0.63 & Portugal & 0.38 \\
Germany & 0.51 & Ireland & 0.32 \\
United Kingdom & 0.50 & Austria & 0.31 \\
\hline \multicolumn{2}{l}{ Source: OECD $(2000)$} &
\end{tabular}


while North Sea oil and gas revenues are declining. But there are also discretionary elements. First, a political accord (the "tax freeze") caps tax rates, causing specific taxes - such as the real estate tax - to fall in real terms. Second, an unfinanced cut in personal income taxes, enacted in 2007, becomes fully effective in 2009. Third, a public sector wage agreement was negotiated this past spring and locks in wage increases of 12 percent over the next three years. And finally public consumption is projected to rise by 1 percentage point of GDP over the period. Taken together, these trends and policies will reduce the structural surplus from over 2 percent of GDP in 2007 to about zero by 2015 .

\section{For 2009, the mission and the authorities agreed in September that a close-to-} neutral fiscal stance would be appropriate. While the economic slowdown was generating political pressure for fiscal stimulus, the authorities emphasized that the economy was still above capacity and unemployment was just bottoming out at an exceptionally low level. Moreover, automatic stabilizers could be expected to cushion the slowdown, and indeed a more serious recession, should it occur. Under the circumstances, they laid more emphasis on the salutary role of a slowdown in breaking wage momentum. Staff shared these views and also emphasized the need for a tight fiscal position to support long run sustainability. In the event, the adopted budget was in line with the targeted medium-term path described above, implying a fiscal injection — over and above automatic stabilizers - of about 0.6 percent of GDP. ${ }^{4}$

\section{Fiscal sustainability}

21. Denmark was among the first in the OECD to articulate and implement a longterm fiscal framework that addressed demographic challenges. The strategy rests on two pillars - accumulating assets while demographics and North Sea revenues are relatively favorable and implementing structural reforms to contain costs in the long run. In particular:

- The government's 2015 plan pre-finances oldage-related spending with structural surpluses that are targeted in a $3 / 4$ to $13 / 4$ percent of GDP range through 2010 and above zero through 2015 (chart). This would raise net government assets to about 10 percent of GDP in 2015 , after which they would start being drawn down.

Projected Fiscal Balances, 2007-15

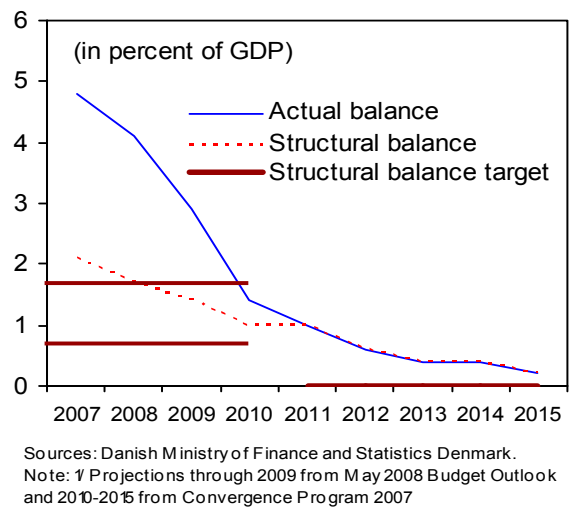

- $\quad$ Several waves of reforms have been implemented over the last two decades. The most important was the 2006 Welfare

\footnotetext{
4 This corresponds to a 0.4 percentage point change in the authorities' estimate of the structural balance as of August 2008.
} 
Agreement which will raise the age thresholds for voluntary early retirement pension — starting in 2019 — and old age pension — starting in 2024 — and then index them to longevity. By reducing the old age dependency ratio (text charts), the Welfare Agreement improved the long-run structural fiscal balance by about 4 percentage points of GDP, effectively closing the long term fiscal gap. ${ }^{5}$ More recently, the 2007 Job Plan strengthened work incentives for pensioners, persons on disability, and the unemployed.

Denmark: Impact of the Welfare Agreement on labor supply and the dependency ratio
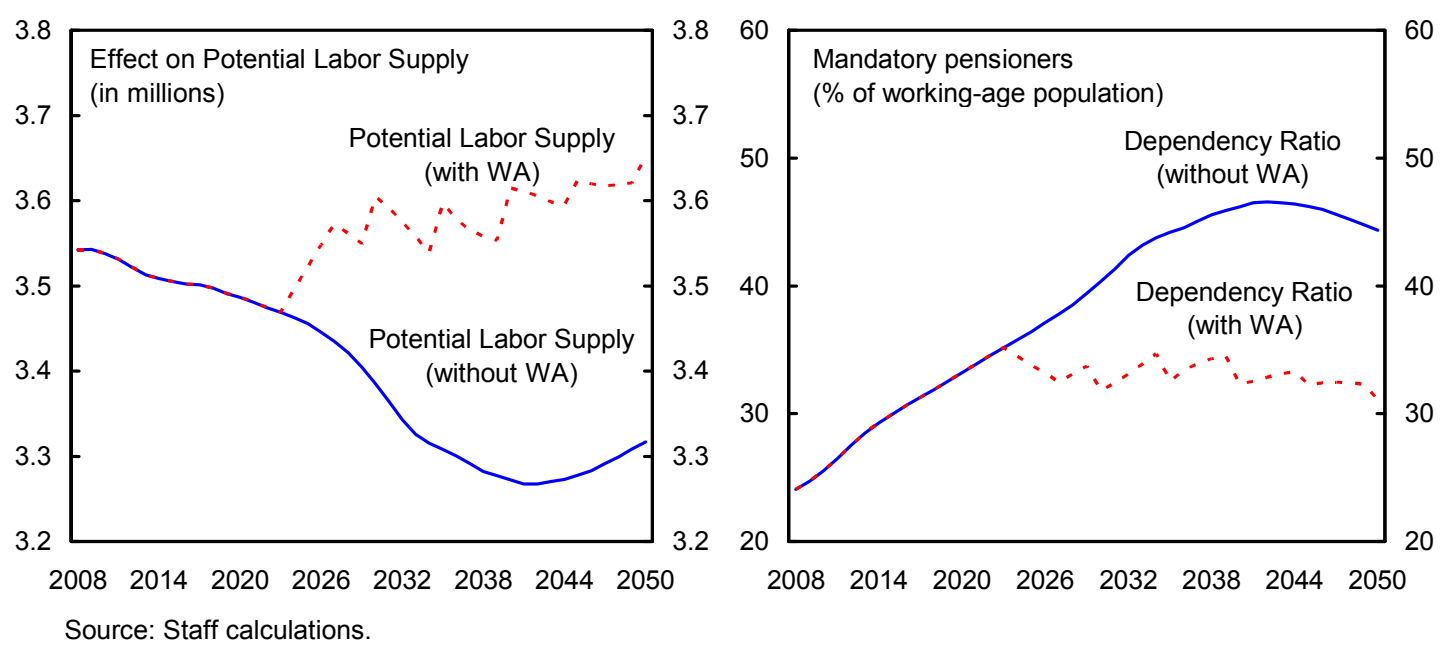

\section{Nevertheless, the authorities recognize that further measures are now needed.}

The tax freeze through 2015, the personal income tax cuts effective in 2009, and the government's energy strategy, among other factors create a sustainability gap that would be filled by a permanent increase in the structural balance by 0.8 percent of GDP (text table). A Tax Commission (due to report in February 2009) and a Labor Market Commission (which issued a preliminary report in September 2008) have been established to come up with proposals:

\begin{tabular}{lr}
\multicolumn{2}{c}{ Denmark: Fiscal Sustainability Gap } \\
\hline 2006 Convergence Program & -0.2 \\
& \\
Structural Changes and Revisions & 0.2 \\
2006 Convergence Program (revised) & $\mathbf{0 . 0}$ \\
Subsequent Policies & \\
Personal Income Tax Cuts & -0.6 \\
Tax Freeze to 2015 & -0.3 \\
Other Tax Changes & 0.6 \\
Energy Strategy & -0.3 \\
Public Consumption & -0.1 \\
Public Investment & -0.1 \\
Sustainability Gap & $\mathbf{- 0 . 8}$ \\
\hline Source: Ministry of Finance and IMF staff calculations
\end{tabular}

\footnotetext{
${ }^{5}$ It also covers the EC Ageing Working Group's 2005 estimate of long-run ageing costs of 3.6 percent of GDP.

${ }^{6}$ See the selected issues paper "Demographic Changes and Fiscal Sustainability in Denmark" by Allan D. Brunner.
} 
- The mandate of the Tax Commission is to improve work incentives by lowering marginal tax rates on labor income. The commission is free, in principle, to propose compensating increases in other taxes-a welcome temporary thaw in the six year "tax freeze". But its ability to strengthen medium-term sustainability is limited. First, the commission is required to present a revenue-neutral overall package. Second, real estate taxes are off the table - the commission does not have the mandate to reverse the decline in the effective tax rate caused by the freeze in assessed property values.

- In contrast, the Labor Market Commission's mandate is to improve long-term public finances. The Commission recently released a number of proposals-accelerate the Welfare Agreement's program to raise the pension age, reduce the duration of unemployment benefits, shift the focus of active labor market programs from education to on-the-job training, and improve the recruitment of foreign labor. While these proposals would go a long way toward improving fiscal sustainability, the public reaction has been overwhelmingly negative, based on the view that it is too soon to re-negotiate the terms of the 2006 Welfare Agreement.

23. The mission discussed challenges and risks to closing the longer-term fiscal gap. First the fiscal benefits of the Welfare Agreement - and the cost to retirees - are back-loaded to 2019. While this allows ample time for planning; it also entails some risk that the political commitment may falter as implementation draws nearer. Second, policy measures to achieve the targets of the 2015 plan have not yet been identified. Third, there is a great deal of uncertainty regarding the fiscal costs of ageing, especially with respect to health and old-age care. Analysis by staff and by independent researchers suggests that the authorities' assumptions might too optimistic. Fourth, Denmark will need to open its borders to the EU New Member States at end-2010. While most studies show that inward migration from these states is likely to have an insignificant effect on public finances, there are concerns that fiscal sustainability could be weakened by individuals gaming the eligibility rules. Finally, there are uncertainties associated with sustaining fiscal discipline at the local government levelthough in this area some recent reforms look promising.

\section{STAFF APPRAISAL}

\section{Denmark has weathered the global crisis well so far but conditions are still}

fragile. The economy is still cyclically strong but the weakening global outlook has increased the risk of a severe downturn. Financial markets' shift towards risk-free liquid assets has put pressure on the exchange rate peg and widened interest rate spreads - between krone and euro as well as between government bonds and mortgage bonds. Against this background, policies need to address three challenges - find the right balance in steering the economy to a soft landing; support financial stability; and ensure that a decade-long effort to strengthen fiscal sustainability does not stall. 
25. Macroeconomic policies need to be set in light of the exchange rate peg. The peg has served Denmark well - anchoring inflationary expectations and keeping interest rates within narrow spreads relative to the euro zone. The authorities' supportive policy stance-a steady hand on fiscal policy through the crisis and a readiness to raise interest rates in the face of reserve outflows - is thus welcome.

26. The proposed 2009 budget strikes a good balance between allowing growth to slow and cushioning it from a severe recession. The 2007 cyclical slowdown was welcome given record low unemployment and fast rising wages, but the global crisis has increased the risk of a hard landing. Given the deterioration in the global outlook, the authorities' 2009 budget proposal — which adds a discretionary positive impulse to the automatic stabilizersis appropriate notwithstanding concerns about medium term sustainability.

27. The authorities' responses to the financial crisis were innovative, forceful, and timely. The new liquidity facilities are comprehensive and the collaborative approach to resolving problem banks facilitated prompt decision-making and prevented contagion during a period of exceptionally fragile confidence.

28. The new financial stability act establishes clear rules and sound incentives. The main features of the agreement — a blanket guarantee and a transparent procedure for preemptive resolution should help secure creditor confidence. The burden-sharing rule protects the taxpayer but has contributed to a decline in banks' share values. Other measuresintrusive but temporary - improve incentives for prudent behavior: the dividend moratorium will strengthen capital buffers; the greater powers extended to the DFSA punish risk-taking; and the elimination of shareholder control in a wound-up bank creates an incentive for preemptive private sector solutions. Also welcome are provisions that level the playing field in cross-border banking operations.

\section{Current conditions underscore the importance of intensifying financial sector} surveillance and supervision. The DFSA's initiative to monitor liquidity risk more frequently and comprehensively is welcome. Although financial stability work is well established, there is scope for further strengthening, and it is important to ensure that the DFSA has the resources to recruit and retain appropriate staff in light of their expanded mandate under Basel II- the recently agreed increase is welcome.

30. Competitiveness is adequate, but recent trends are unsustainable. The REER is well aligned, but wages are rising faster than in trading partners while productivity is rising slower. Wage growth needs to slow if firms are to rebuild profitability and stem the decline in Denmark's export share. Otherwise firms will be stressed by a simultaneous increase in costs and slowdown in demand.

31. Upfront action is needed to ensure fiscal sustainability. The achievements of the past two decades have been remarkable, but they do not close the long-term fiscal gap. 
Difficult choices are required in order to make the welfare state compatible with labor market incentives and long term fiscal balance.

- $\quad$ Tax reform needs to be more comprehensive. A broader set of measures should be considered, including user fees, the indexation of the tax on residential property and reducing the deductibility of mortgage interest.

- $\quad$ On the expenditure side, the proposals recently presented by the Labor Market Commission deserve careful consideration.

32. Denmark's continued generous provision of foreign aid is welcome. Denmark is committed to maintaining development assistance at the internationally high level of 0.8 percent of gross national income.

33. Staff recommends that Denmark remain on the 24-month consultation cycle. 
Table 1. Denmark: Selected Economic and Social Indicators, 2000-08

\begin{tabular}{|c|c|c|c|c|c|c|c|c|c|}
\hline & 2000 & 2001 & 2002 & 2003 & 2004 & 2005 & 2006 & 2007 & $\begin{array}{l}2008 \\
\text { proj. }\end{array}$ \\
\hline \multicolumn{10}{|l|}{ Supply and Demand (change in percent) } \\
\hline Real GDP & 3.5 & 0.7 & 0.5 & 0.4 & 2.3 & 2.5 & 3.9 & 1.7 & 0.6 \\
\hline Net Exports 1/ & 0.6 & 0.7 & -1.1 & 0.2 & -2.0 & -1.1 & -2.3 & -1.0 & -0.4 \\
\hline Domestic demand & 3.2 & 0.0 & 1.7 & 0.2 & 4.1 & 4.3 & 5.1 & 3.1 & 1.6 \\
\hline Private Consumption & 0.2 & 0.1 & 1.5 & 1.0 & 4.7 & 5.2 & 3.8 & 2.3 & 1.8 \\
\hline Gross fixed investment & 7.4 & -1.4 & 0.1 & -0.2 & 3.9 & 6.1 & 14.0 & 5.9 & 0.0 \\
\hline Gross national saving (percent of GDP) & 22.6 & 23.5 & 22.7 & 23.0 & 23.2 & 24.0 & 24.6 & 23.6 & 24.1 \\
\hline Gross domestic investment (percent of GDP) & 21.2 & 20.4 & 20.4 & 19.6 & 20.4 & 20.1 & 22.5 & 23.4 & 23.2 \\
\hline Potential output & 2.5 & 2.3 & 1.4 & 1.3 & 1.0 & 1.4 & 2.0 & 2.5 & 1.8 \\
\hline Output gap (in percent of total output) & 2.3 & 0.7 & -0.2 & -1.1 & 0.1 & 1.2 & 3.1 & 2.3 & 1.0 \\
\hline \multicolumn{10}{|l|}{ Labor Market (change in percent) } \\
\hline Labor force & 0.5 & 0.1 & -1.1 & -0.2 & -0.2 & 0.1 & 1.0 & 0.6 & 0.2 \\
\hline Employment & 0.8 & 0.9 & -1.2 & -1.2 & -0.4 & 0.9 & 2.2 & 1.8 & 1.3 \\
\hline Unemployment rate (in percent) & 5.4 & 4.7 & 4.8 & 5.7 & 5.8 & 5.1 & 3.9 & 2.8 & 1.8 \\
\hline \multicolumn{10}{|l|}{ Prices and Costs (change in percent) } \\
\hline GDP deflator & 3.0 & 2.5 & 2.3 & 1.6 & 2.3 & 3.1 & 2.0 & 1.7 & 5.4 \\
\hline $\mathrm{CPI}$ (year average) & 2.9 & 2.4 & 2.4 & 2.1 & 1.2 & 1.8 & 1.9 & 1.7 & 3.4 \\
\hline Unit labor costs (manufacturing) & -0.7 & 3.7 & 3.7 & 1.9 & -2.9 & -0.4 & 1.6 & 1.5 & 1.8 \\
\hline \multicolumn{10}{|l|}{ Public finance (percent of GDP) 2/ } \\
\hline General government revenues & 56.2 & 55.7 & 55.1 & 55.2 & 56.7 & 57.9 & 56.3 & 55.7 & 53.4 \\
\hline General government expenditure & 53.9 & 54.5 & 54.9 & 55.3 & 54.8 & 52.9 & 51.4 & 50.9 & 50.2 \\
\hline General government balance & 2.3 & 1.2 & 0.2 & -0.1 & 1.9 & 5.0 & 4.9 & 4.8 & 3.2 \\
\hline General government structural balance 3/ & 1.0 & 1.0 & 0.4 & 0.9 & 1.6 & 2.7 & 2.7 & 3.5 & 2.3 \\
\hline General government primary balance & 4.9 & 3.5 & 2.5 & 1.9 & 3.4 & 6.2 & 5.8 & 5.4 & 3.5 \\
\hline General government gross debt & 51.5 & 48.7 & 48.3 & 45.8 & 43.8 & 36.4 & 30.4 & 26.0 & 21.3 \\
\hline \multicolumn{10}{|l|}{ Money and Interest rates (percent) } \\
\hline Domestic credit growth (end of year) & 11.5 & 9.5 & 5.1 & 6.3 & 8.9 & 14.9 & 14.1 & 13.0 & --- \\
\hline M3 growth (end of year) & -5.2 & 7.7 & 11.9 & 11.3 & 2.7 & 14.3 & 11.4 & 17.0 & --- \\
\hline Short-term interest rate (3 month) & 4.9 & 4.6 & 3.5 & 2.4 & 2.1 & 2.2 & 3.1 & 4.3 & --- \\
\hline Government bond yield (10 year) & 5.7 & 5.1 & 5.1 & 4.3 & 4.3 & 3.4 & 3.9 & 4.4 & --- \\
\hline \multicolumn{10}{|l|}{ Balance of payments (in percent of GDP) } \\
\hline Exports of goods \& services & 46.6 & 47.2 & 47.2 & 45.3 & 45.4 & 49.2 & 51.8 & 52.2 & 53.9 \\
\hline Imports of goods & 40.5 & 40.6 & 41.4 & 39.1 & 40.5 & 44.3 & 49.1 & 50.9 & 52.1 \\
\hline Trade balance, goods and services & 6.0 & 6.6 & 5.8 & 6.3 & 4.9 & 4.9 & 2.7 & 1.3 & 1.9 \\
\hline Of which: net oil exports (US\$ bln) & 1.5 & 1.0 & 1.4 & 1.8 & 2.6 & 3.2 & 3.8 & 3.8 & 3.8 \\
\hline Current account & 1.4 & 3.1 & 2.5 & 3.4 & 3.1 & 4.4 & 2.9 & 1.1 & 0.9 \\
\hline \multicolumn{10}{|l|}{ Exchange rate } \\
\hline Exchange rate regime & \multicolumn{9}{|c|}{ ERM2 Participant } \\
\hline Average $\mathrm{DKr}$ per US\$ rate & 8.1 & 8.3 & 7.9 & 6.6 & 6.0 & 6.0 & 5.9 & 5.4 & --- \\
\hline Nominal effective rate $(2000=100$, ULC based $)$ & 100.0 & 101.5 & 102.7 & 107.4 & 108.9 & 108.4 & 108.7 & 110.9 & --- \\
\hline Real effective rate $(2000=100$, ULC based $)$ & 100.0 & 102.8 & 106.8 & 113.8 & 113.0 & 112.4 & 113.9 & 119.2 & -- \\
\hline \multicolumn{10}{|l|}{ Social indicators (Reference year) } \\
\hline
\end{tabular}

Sources: IMF, World Economic Outlook; Danmarks Nationalbank; Statistics Denmark; OECD; Eurostat; and IMF staff projections.

$1 /$ Contribution to GDP growth.

2/ Figures for 2007-08 reflect Ministry of Finance estimates and projections as of August 2007; pre-2007 numbers are from Danmarks Statistik.

$3 /$ In percent of potential GDP 
Table 2. Denmark. Medium-term Scenario, 2005-13

(Percentage change, unless otherwise indicated)

\begin{tabular}{|c|c|c|c|c|c|c|c|c|c|}
\hline & 2005 & 2006 & 2007 & 2008 & 2009 & 2010 & 2011 & 2012 & 2013 \\
\hline Real GDP & 2.5 & 3.9 & 1.7 & 0.6 & 0.3 & 0.4 & 1.1 & 1.6 & 1.6 \\
\hline Real domestic demand & 4.3 & 5.1 & 3.1 & 1.6 & -0.2 & 0.3 & 1.1 & 1.9 & 1.9 \\
\hline Private consumption & 5.2 & 3.8 & 2.3 & 1.8 & 0.8 & 1.1 & 2.4 & 2.2 & 2.2 \\
\hline Public consumption & 0.9 & 2.0 & 1.6 & 1.5 & 1.0 & 1.0 & 1.0 & 0.8 & 0.8 \\
\hline Fixed investment & 6.1 & 14.0 & 5.9 & 0.0 & -3.5 & -2.6 & -1.9 & 2.4 & 2.4 \\
\hline Change in stocks $1 /$ & -0.7 & 0.6 & -0.3 & 0.3 & 0.0 & 0.0 & 0.0 & 0.0 & 0.0 \\
\hline Net exports 1/ & -1.1 & -2.3 & -1.0 & -0.4 & 0.4 & 0.2 & 0.0 & -0.3 & -0.3 \\
\hline Exports & 8.3 & 9.0 & 1.9 & 1.9 & 1.0 & 3.3 & 2.0 & 3.3 & 3.3 \\
\hline Imports & 11.3 & 14.1 & 3.8 & 2.6 & 0.2 & 3.0 & 2.0 & 3.8 & 3.8 \\
\hline Current account 2/ & 4.4 & 2.9 & 1.1 & 0.9 & 0.5 & 0.8 & 0.8 & 0.6 & 0.4 \\
\hline \multicolumn{10}{|l|}{ Inflation } \\
\hline Consumer Prices & 1.8 & 1.9 & 1.7 & 3.4 & 2.3 & 2.1 & 1.9 & 1.9 & 1.9 \\
\hline \multicolumn{10}{|l|}{ Labor market } \\
\hline Employment & 0.9 & 2.2 & 1.8 & 1.3 & -0.9 & -0.6 & -0.2 & -0.1 & -0.3 \\
\hline Average unemployment rate & 5.1 & 3.9 & 2.8 & 1.8 & 3.0 & 3.7 & 4.0 & 4.0 & 4.0 \\
\hline \multicolumn{10}{|l|}{ Public finance } \\
\hline General government balance 2/ & 5.0 & 4.9 & 4.8 & 3.2 & 2.1 & 0.8 & 0.4 & 0.2 & 0.3 \\
\hline General government structural balance 3/ & 2.7 & 2.7 & 3.5 & 2.3 & 1.1 & 0.8 & 0.6 & 0.3 & 0.3 \\
\hline General government gross debt $2 /$ & 36.4 & 30.4 & 26.0 & 21.3 & 18.8 & 17.5 & 16.5 & 15.7 & 14.8 \\
\hline Output gap $3 /$ & 1.2 & 3.1 & 2.3 & 1.0 & -0.1 & -0.7 & -0.3 & -0.1 & 0.0 \\
\hline
\end{tabular}

Sources: Danmarks Nationalbank, Statistics Denmark, and IMF staff estimates.

$1 /$ Contributions to growth

2/ In percent of GDP

3/ In percent of potential output. Structural balance estimates differ from the Ministry of Finance owing to differences in

(i) unemployment gap estimates; (ii) one-off changes to certain budget items; and (iii) accounting methodology. 
Table 3. Denmark: Balance of Payments, 2004-13

\begin{tabular}{|c|c|c|c|c|c|c|c|c|c|c|}
\hline & 2004 & 2005 & 2006 & 2007 & 2008 & 2009 & 2010 & 2011 & 2012 & 2013 \\
\hline & \multicolumn{9}{|c|}{ (in billions of DKr) } & \\
\hline Current Account & 44.7 & 68.3 & 48.2 & 19.1 & 16.3 & 10.1 & 15.2 & 16.4 & 12.8 & 8.4 \\
\hline Balance on Goods & 55.1 & 45.1 & 17.1 & -4.7 & -11.7 & -16.2 & -13.8 & -13.1 & -16.3 & -20.0 \\
\hline Merchandise exports f.o.b. & 447.7 & 495.9 & 537.9 & 547.9 & 603.0 & 614.2 & 643.3 & 660.7 & 694.5 & 728.7 \\
\hline Merchandise imports f.o.b. & -392.6 & -450.8 & -520.8 & -552.6 & -614.7 & -630.5 & -657.1 & -673.8 & -710.8 & -748.8 \\
\hline Balance on Services & 19.8 & 38.3 & 42.0 & 40.4 & 45.7 & 44.3 & 47.5 & 48.6 & 48.9 & 48.9 \\
\hline Exports of services, total & 218.9 & 260.5 & 312.2 & 333.8 & 367.5 & 374.3 & 390.1 & 396.8 & 413.1 & 429.2 \\
\hline Imports of services, total & -199.1 & -222.2 & -270.2 & -293.3 & -321.8 & -330.0 & -342.6 & -348.2 & -364.2 & -380.3 \\
\hline Balance on Income & -2.4 & 9.9 & 16.5 & 11.4 & 12.0 & 12.3 & 12.6 & 13.0 & 13.5 & 14.0 \\
\hline Receipts & 92.1 & 149.5 & 164.0 & 190.7 & 202.3 & 206.5 & 212.3 & 219.0 & 227.2 & 235.4 \\
\hline Expenditures & -94.5 & -139.6 & -147.5 & -179.4 & -190.2 & -194.2 & -199.7 & -206.0 & -213.6 & -221.3 \\
\hline Current transfer, net & -27.7 & -25.0 & -27.4 & -28.0 & -29.7 & -30.3 & -31.2 & -32.1 & -33.3 & -34.5 \\
\hline Capital and Financial Account & -103.7 & -48.2 & -18.0 & -29.7 & -16.3 & -10.1 & -15.2 & -16.4 & -12.8 & -8.4 \\
\hline Capital transfer, net & 0.2 & 2.9 & 0.0 & 0.3 & 0.3 & 0.3 & 0.3 & 0.3 & 0.3 & 0.4 \\
\hline Financial Account & -103.9 & -51.1 & -18.0 & -30.0 & -16.6 & -10.4 & -15.5 & -16.7 & -13.2 & -8.7 \\
\hline Direct investment, net & -0.5 & -19.8 & -29.0 & -31.4 & -33.3 & -34.0 & -35.0 & -36.1 & -37.4 & -38.8 \\
\hline Abroad & 62.1 & -97.1 & -50.5 & -92.5 & -98.1 & -100.1 & -102.9 & -106.2 & -110.1 & -114.1 \\
\hline In Denmark & -62.6 & 77.3 & 21.5 & 61.1 & 64.8 & 66.1 & 68.0 & 70.1 & 72.7 & 75.3 \\
\hline Portfolio investment, net & -147.4 & -191.8 & -155.0 & -154.4 & -163.8 & -167.2 & -171.9 & -177.3 & -183.9 & -190.6 \\
\hline Assets & -43.0 & -84.2 & -133.2 & -50.9 & -54.0 & -55.1 & -56.6 & -58.4 & -60.6 & -62.8 \\
\hline Liabilities & -104.4 & -107.5 & -21.8 & -103.6 & -109.8 & -112.1 & -115.3 & -118.9 & -123.3 & -127.8 \\
\hline Other investment, net & -41.7 & 11.2 & 66.7 & 49.2 & 52.2 & 53.3 & 54.8 & 56.5 & 58.6 & 60.7 \\
\hline Reserve assets & 6.2 & 11.8 & 37.9 & 1.2 & 16.5 & 23.4 & 19.2 & 19.1 & 24.0 & 29.8 \\
\hline \multirow[t]{2}{*}{ Net errors and omissions } & 59.0 & -20.1 & -30.2 & 10.6 & 0.0 & 0.0 & 0.0 & 0.0 & 0.0 & 0.0 \\
\hline & \multicolumn{9}{|c|}{ (percent of GDP) } & \\
\hline Current Account & 3.1 & 4.4 & 2.9 & 1.1 & 0.9 & 0.5 & 0.8 & 0.8 & 0.6 & 0.4 \\
\hline Balance on Goods & 3.8 & 2.9 & 1.0 & -0.3 & -0.7 & -0.9 & -0.7 & -0.7 & -0.8 & -1.0 \\
\hline Merchandise exports f.o.b. & 30.5 & 32.0 & 32.8 & 32.3 & 33.5 & 33.4 & 34.1 & 33.9 & 34.4 & 34.8 \\
\hline Merchandise imports f.o.b. & -26.8 & -29.1 & -31.7 & -32.6 & -34.2 & -34.3 & -34.8 & -34.6 & -35.2 & -35.8 \\
\hline Balance on Services & 1.3 & 2.5 & 2.6 & 2.4 & 2.5 & 2.4 & 2.5 & 2.5 & 2.4 & 2.3 \\
\hline Exports of services, total & 14.9 & 16.8 & 19.0 & 19.7 & 20.4 & 20.4 & 20.7 & 20.4 & 20.4 & 20.5 \\
\hline Imports of services, total & -13.6 & -14.4 & -16.5 & -17.3 & -17.9 & -18.0 & -18.1 & -17.9 & -18.0 & -18.2 \\
\hline Balance on Income & -0.2 & 0.6 & 1.0 & 0.7 & 0.7 & 0.7 & 0.7 & 0.7 & 0.7 & 0.7 \\
\hline Receipts & 6.3 & 9.7 & 10.0 & 11.2 & 11.2 & 11.2 & 11.2 & 11.2 & 11.2 & 11.2 \\
\hline Expenditures & -6.4 & -9.0 & -9.0 & -10.6 & -10.6 & -10.6 & -10.6 & -10.6 & -10.6 & -10.6 \\
\hline Current transfer, net & -1.9 & -1.6 & -1.7 & -1.7 & -1.7 & -1.7 & -1.7 & -1.7 & -1.7 & -1.7 \\
\hline Capital and Financial Account & -7.1 & -3.1 & -1.1 & -1.7 & -0.9 & -0.5 & -0.8 & -0.8 & -0.6 & -0.4 \\
\hline Capital transfer, net & 0.0 & 0.2 & 0.0 & 0.0 & 0.0 & 0.0 & 0.0 & 0.0 & 0.0 & 0.0 \\
\hline Financial Account & -7.1 & -3.3 & -1.1 & -1.8 & -0.9 & -0.6 & -0.8 & -0.9 & -0.7 & -0.4 \\
\hline Direct investment, net & 0.0 & -1.3 & -1.8 & -1.9 & -1.9 & -1.9 & -1.9 & -1.9 & -1.9 & -1.9 \\
\hline Abroad & 4.2 & -6.3 & -3.1 & -5.5 & -5.5 & -5.5 & -5.5 & -5.5 & -5.5 & -5.5 \\
\hline In Denmark & -4.3 & 5.0 & 1.3 & 3.6 & 3.6 & 3.6 & 3.6 & 3.6 & 3.6 & 3.6 \\
\hline Portfolio investment, net & -10.1 & -12.4 & -9.4 & -9.1 & -9.1 & -9.1 & -9.1 & -9.1 & -9.1 & -9.1 \\
\hline Assets & -2.9 & -5.4 & -8.1 & -3.0 & -3.0 & -3.0 & -3.0 & -3.0 & -3.0 & -3.0 \\
\hline Liabilities & -7.1 & -6.9 & -1.3 & -6.1 & -6.1 & -6.1 & -6.1 & -6.1 & -6.1 & -6.1 \\
\hline Other investment, net & -2.8 & 0.7 & 4.1 & 2.9 & 2.9 & 2.9 & 2.9 & 2.9 & 2.9 & 2.9 \\
\hline Reserve assets & 0.4 & 0.8 & 2.3 & 0.1 & 0.9 & 1.3 & 1.0 & 1.0 & 1.2 & 1.4 \\
\hline Net errors and omissions & 4.0 & -1.3 & -1.8 & 0.6 & 0.0 & 0.0 & 0.0 & 0.0 & 0.0 & 0.0 \\
\hline Memorandum items: & & & & (perc & ent of $\mathrm{G}$ & & & & & \\
\hline Net oil and oil-related exports & 1.1 & 1.2 & 1.4 & 1.2 & $\ldots$ & $\ldots$ & $\ldots$ & $\ldots$ & $\ldots$ & $\ldots$ \\
\hline Net sea transportation receipts & 1.3 & 2.9 & 2.8 & 2.7 & $\ldots$ & $\ldots$ & $\ldots$ & $\ldots$ & $\ldots$ & $\ldots$ \\
\hline Current Account net of items above & 0.6 & 0.3 & -1.2 & -2.7 & $\ldots$ & $\ldots$ & $\ldots$ & $\ldots$ & $\ldots$ & \\
\hline Gross External Debt & 131.1 & 146.5 & 155.6 & 169.6 & 184.8 & 205.9 & 225.1 & 243.1 & 259.2 & 275.0 \\
\hline Net External Debt & 20.9 & 17.9 & 29.7 & 32.0 & 33.3 & 36.1 & 38.3 & 40.3 & 42.3 & 44.4 \\
\hline
\end{tabular}

Sources: Danmarks Nationalbank, Statistics Denmark, and IMF staff calculations. 
Table 4. Denmark: Net Investment Position, 2001-07 (in percent of GDP)

\begin{tabular}{|c|c|c|c|c|c|c|c|}
\hline & 2001 & 2002 & 2003 & 2004 & 2005 & 2006 & 2007 \\
\hline Assets & 152.6 & 144.2 & 158.5 & 171.6 & 202.6 & 205.5 & 221.9 \\
\hline Direct investment abroad & 49.3 & 44.7 & 43.7 & 47.1 & 52.9 & 51.2 & 53.8 \\
\hline Portfolio investment abroad & 53.9 & 44.6 & 54.0 & 62.5 & 80.1 & 86.2 & 89.8 \\
\hline Other investment abroad (incl. financial derivatives) & 38.0 & 40.5 & 44.5 & 46.8 & 55.6 & 57.3 & 68.0 \\
\hline Reserve assets & 11.5 & 14.5 & 16.4 & 15.2 & 14.0 & 10.8 & 10.4 \\
\hline Liabilities & 169.2 & 160.6 & 170.7 & 176.8 & 199.1 & 207.2 & 226.0 \\
\hline Direct investment into Denmark & 47.5 & 42.8 & 42.6 & 43.4 & 47.4 & 46.4 & 47.2 \\
\hline Portfolio investment into Denmark & 70.8 & 65.7 & 67.7 & 74.9 & 85.9 & 86.8 & 91.3 \\
\hline Other investment into Denmark & 50.5 & 51.9 & 60.1 & 58.4 & 65.6 & 73.7 & 87.3 \\
\hline Reserve assets & 0.4 & 0.3 & 0.3 & 0.1 & 0.2 & 0.2 & 0.2 \\
\hline Net investment position & -16.5 & -16.4 & -12.2 & -5.3 & 3.5 & -1.6 & -4.0 \\
\hline Direct investment abroad & 1.8 & 1.9 & 1.1 & 3.7 & 5.6 & 4.8 & 6.6 \\
\hline Portfolio investment abroad & -16.9 & -21.1 & -13.7 & -12.4 & -5.9 & -0.6 & -1.6 \\
\hline Other investment abroad (incl. financial derivatives) & -12.6 & -11.4 & -15.6 & -11.6 & -10.0 & -16.4 & -19.3 \\
\hline Reserve assets & 11.1 & 14.2 & 16.1 & 15.1 & 13.8 & 10.6 & 10.2 \\
\hline
\end{tabular}


Table 5. Denmark Public Finance, 2003-13

(in percent of GDP)

\begin{tabular}{|c|c|c|c|c|c|c|c|c|c|c|c|}
\hline & $\begin{array}{l}2003 \\
\text { Actual }\end{array}$ & $\begin{array}{l}2004 \\
\text { Actual }\end{array}$ & $\begin{array}{l}2005 \\
\text { Actual }\end{array}$ & $\begin{array}{l}2006 \\
\text { Actual }\end{array}$ & $\begin{array}{l}2007 \\
\text { Actual }\end{array}$ & $\begin{array}{r}2008 \\
\text { Staff }\end{array}$ & $\begin{array}{r}2009 \\
\text { Staff }\end{array}$ & $\begin{array}{r}2010 \\
\text { Staff }\end{array}$ & $\begin{array}{r}2011 \\
\text { Staff }\end{array}$ & $\begin{array}{r}2012 \\
\text { Staff }\end{array}$ & $\begin{array}{r}2013 \\
\text { Staff }\end{array}$ \\
\hline \multicolumn{12}{|l|}{ General Government } \\
\hline Total Revenues & 55.2 & 56.7 & 57.9 & 56.3 & 55.7 & 53.4 & 52.4 & 52.4 & 52.3 & 52.3 & 52.5 \\
\hline Personal Income Taxes & 27.3 & 26.7 & 26.6 & 26.0 & 26.5 & 25.2 & 23.6 & 24.2 & 24.6 & 24.8 & 25.0 \\
\hline Labor Market Contributions & 4.4 & 4.4 & 4.4 & 4.4 & 4.5 & 4.4 & 4.4 & 4.3 & 4.3 & 4.3 & 4.2 \\
\hline Pension Return Taxes & 0.4 & 1.6 & 2.4 & 0.8 & 0.4 & 0.0 & 0.9 & 0.8 & 1.0 & 1.0 & 1.0 \\
\hline Company Taxes & 2.9 & 3.2 & 3.9 & 4.3 & 3.6 & 3.7 & 3.5 & 2.9 & 2.2 & 2.2 & 2.2 \\
\hline VAT & 9.6 & 9.8 & 10.0 & 10.3 & 10.4 & 10.1 & 10.1 & 10.4 & 10.5 & 10.5 & 10.5 \\
\hline Social Contributions & 1.2 & 1.2 & 1.1 & 1.0 & 1.0 & 1.0 & 1.0 & 1.0 & 1.0 & 1.0 & 1.0 \\
\hline Interest and Dividends & 1.5 & 1.5 & 1.3 & 1.3 & 1.4 & 1.4 & 1.4 & 1.3 & 1.4 & 1.4 & 1.4 \\
\hline Other revenues & 7.9 & 8.4 & 8.2 & 8.2 & 7.9 & 7.7 & 7.6 & 7.4 & 7.4 & 7.2 & 7.1 \\
\hline Total Expenditures & 55.3 & 54.8 & 52.9 & 51.4 & 50.9 & 50.2 & 50.3 & 51.6 & 51.9 & 52.1 & 52.2 \\
\hline Public Consumption & 27.6 & 27.6 & 27.1 & 26.8 & 26.9 & 26.7 & 26.6 & 27.0 & 27.1 & 27.3 & 27.5 \\
\hline Transfer Incomes & 17.4 & 17.1 & 16.5 & 15.5 & 15.2 & 14.6 & 15.4 & 16.4 & 16.6 & 16.6 & 16.6 \\
\hline Public Subsidies & 2.4 & 2.3 & 2.3 & 2.2 & 2.2 & 2.2 & 2.3 & 2.4 & 2.4 & 2.4 & 2.4 \\
\hline Interest Expenditures & 3.4 & 3.1 & 2.6 & 2.2 & 2.0 & 1.7 & 1.6 & 1.3 & 1.3 & 1.3 & 1.2 \\
\hline Public Investment & 1.6 & 1.9 & 1.7 & 1.8 & 1.9 & 1.9 & 1.9 & 1.8 & 1.8 & 1.8 & 1.8 \\
\hline Other Expenditures & 2.8 & 2.8 & 2.8 & 2.8 & 2.7 & 3.2 & 2.7 & 2.7 & 2.7 & 2.7 & 2.7 \\
\hline Balance & -0.1 & 1.9 & 5.0 & 4.9 & 4.8 & 3.2 & 2.1 & 0.8 & 0.4 & 0.2 & 0.3 \\
\hline Primary balance & 1.9 & 3.4 & 6.2 & 5.8 & 5.4 & 3.5 & 2.3 & 0.8 & 0.3 & 0.1 & 0.1 \\
\hline Structural balance 1/ & 0.9 & 1.6 & 2.7 & 2.6 & 3.4 & 2.2 & 1.1 & 0.8 & 0.6 & 0.3 & 0.3 \\
\hline Gross Debt & 45.8 & 43.8 & 36.4 & 30.4 & 26.0 & 21.3 & 18.8 & 17.5 & 16.5 & 15.7 & 14.8 \\
\hline \multicolumn{12}{|l|}{ Central Government } \\
\hline Total revenues & 34.8 & 36.5 & 38.0 & 37.2 & 40.7 & 38.6 & 37.6 & 37.2 & 37.0 & 37.0 & 37.1 \\
\hline Total expenditures & 34.9 & 34.6 & 32.7 & 31.9 & 35.9 & 35.4 & 35.5 & 36.4 & 36.6 & 36.8 & 36.8 \\
\hline Balance & -0.12 & 1.88 & 5.31 & 5.30 & 4.76 & 3.1 & 2.0 & 0.8 & 0.4 & 0.2 & 0.2 \\
\hline
\end{tabular}

Source: Statistics Denmark and IMF Staff calculations.

Note: 1 / The structural balance estimates differ from those of the Ministry of Finance due to: differences in (i) unemployment gap estimates; (ii) estimates of one-off, non-cyclical changes to certain budget items; and in (iii) accounting methodology. 


\begin{tabular}{|c|c|c|c|c|c|c|}
\hline & 2003 & 2004 & 2005 & 2006 & 2007 & 2008 \\
\hline \multicolumn{7}{|l|}{ External Indicators } \\
\hline Exports (annual percentage change, in U.S. dollars) & 18.5 & 12.9 & 8.2 & 9.8 & 11.3 & $\ldots$ \\
\hline Imports (annual percentage change, in U.S. dollars) & 17.7 & 18.3 & 11.2 & 15.0 & 13.4 & $\ldots$ \\
\hline Terms of trade (annual percentage change) & 1.0 & 1.2 & 2.0 & -0.5 & -1.2 & $\ldots$ \\
\hline Current account balance (percent of GDP) & 3.4 & 3.1 & 4.4 & 2.9 & 1.1 & $\ldots$ \\
\hline Inward portfolio investment (in percent of GDP) & 3.2 & 4.1 & 8.0 & 2.7 & 6.1 & $\ldots$ \\
\hline Inward foreign direct investment (percent of GDP) & 1.3 & -4.3 & 5.0 & 1.3 & 3.6 & $\ldots$ \\
\hline Official reserves (in billions of U.S. dollars, end-of-period) & 38.1 & 40.1 & 33.9 & 31.0 & 33.8 & $\ldots$ \\
\hline Official reserves in months of imports & 4.8 & 4.3 & 3.8 & 2.7 & 2.6 & $\ldots$ \\
\hline Exchange rate per U.S. dollar (period average) & 6.6 & 6.0 & 6.0 & 5.9 & 5.4 & $\ldots$ \\
\hline \multicolumn{7}{|l|}{ Financial markets indicators } \\
\hline Public sector debt (Maastricht definition) & 45.8 & 43.8 & 36.4 & 30.4 & 26.0 & $\ldots$ \\
\hline 3-month T-bill yield (percent) & 2.4 & 2.1 & 2.2 & 3.1 & 4.3 & $\ldots$ \\
\hline 3-month T-bill yield (real, percent) & 0.3 & 1.0 & 0.4 & 1.2 & 2.6 & $\ldots$ \\
\hline Spread of 3-month T-bill over EURIBOR (percentage points) & 0.0 & 0.0 & 0.0 & 0.0 & 0.0 & $\ldots$ \\
\hline 10 -year government bond yield (percent) & 4.3 & 4.3 & 3.4 & 3.9 & 4.4 & $\ldots$ \\
\hline 10-year government bond yield (real, percent) & 2.2 & 3.1 & 1.6 & 2.0 & 2.7 & $\ldots$ \\
\hline Spread of 10-year government bond rate with Germany (percentage points) & 0.2 & 0.3 & 0.0 & 0.1 & 0.2 & $\ldots$ \\
\hline Stock market index (period average, 1995-100) & 189.4 & 242.4 & 314.9 & 377.0 & 465.2 & 404.3 \\
\hline \multicolumn{7}{|l|}{ Financial Soundness Indicators } \\
\hline \multicolumn{7}{|l|}{ Capital Adequacy } \\
\hline Regulatory capital to risk-weighted assets (Tier 1+Tier 2) & 13.8 & 13.4 & 13.2 & 13.8 & 12.3 & $\ldots$ \\
\hline Tier 1 capital to risk-weighted assets & 10.6 & 10.7 & 10.2 & 10.9 & 9.2 & $\ldots$ \\
\hline Capital (net worth) to assets $1 /$ & 5.9 & 5.7 & 5.7 & 6.2 & 5.7 & $\ldots$ \\
\hline \multicolumn{7}{|l|}{ Asset Composition and Quality } \\
\hline \multicolumn{7}{|l|}{ Sectoral distribution of lending to residents } \\
\hline Nonfinancial companies & 35.9 & 37.9 & 32.9 & 34.2 & 33.2 & 34.4 \\
\hline Financial institutions & 38.6 & 34.3 & 40.2 & 38.2 & 40.5 & 40.0 \\
\hline General government & 2.1 & 2.3 & 1.6 & 1.9 & 1.4 & 1.6 \\
\hline Households & 22.9 & 24.7 & 24.3 & 24.3 & 23.6 & 22.7 \\
\hline Other & 0.5 & 0.7 & 1.0 & 1.3 & 1.4 & 1.3 \\
\hline Nonperforming loans to gross loans & 0.8 & 0.7 & 0.4 & 0.3 & 0.3 & $\ldots$ \\
\hline Nonperforming loans net of provisions to Tier 1 capital & 2.0 & 1.8 & 0.9 & 0.9 & 1.5 & $\ldots$ \\
\hline Foreign currency loans to total loans & 35.9 & 38.9 & 40.2 & 40.0 & 42.6 & 44.3 \\
\hline Loans to assets & 68.3 & 66.4 & 66.0 & 66.7 & 50.0 & $\ldots$ \\
\hline \multicolumn{7}{|l|}{ Earnings and Profitability } \\
\hline Return on average assets (ROAA) & 1.2 & 1.2 & 1.3 & 1.3 & 1.0 & $\ldots$ \\
\hline Return on average equity (ROAE) & 20.8 & 21.2 & 22.2 & 21.9 & 17.3 & $\ldots$ \\
\hline Net interest income to gross income & 72.2 & 68.5 & 67.0 & 65.3 & 66.7 & $\ldots$ \\
\hline Noninterest expenses to gross income & 60.5 & 63.5 & 60.6 & 66.5 & 67.0 & $\ldots$ \\
\hline \multicolumn{7}{|l|}{ Liquidity } \\
\hline Liquid assets to total assets & 31.3 & 30.4 & 26.5 & 24.4 & 21.3 & $\ldots$ \\
\hline Liquid assets to short term liabilities & 37.6 & 35.7 & 35.1 & 29.7 & 29.2 & 29.1 \\
\hline Gross loans to deposits & 1.0 & 1.0 & 1.1 & 1.3 & 1.3 & $\ldots$ \\
\hline Liquidity coverage as a percentage of the requirement & 153.1 & 189.5 & 176.9 & 140.1 & & $\ldots$ \\
\hline Net external liabilities to total liabilities & 40.6 & 42.5 & 43.9 & 44.9 & 48.8 & 48.9 \\
\hline \multicolumn{7}{|l|}{ Sensitivity to Market Risk } \\
\hline Net open FX position as percent of regulatory capital & 0.2 & 0.5 & 0.7 & 0.8 & 1.1 & $\ldots$ \\
\hline \multicolumn{7}{|l|}{ Indicators for other sectors } \\
\hline Residential property price index $(2006=100)$ & 62.8 & 68.2 & 82.2 & 100.5 & 100.1 & 95.7 \\
\hline
\end{tabular}

Sources: DFSA, Danmarks Nationalbanken, Statistics Denmark, IFS.

1/ Shareholders' equity to total assets.

2/ Included in short-term liabilities are deposits available on demand and time deposits with original maturity of less than a year .

3/ Bank external liabilities net of external assets to total liabilities. 
Table 7. Financial Soundness Indicators of major Danish banks

\begin{tabular}{lrrrr}
\hline & 2005 & \multicolumn{1}{c}{2006} & \multicolumn{1}{c}{2007} & $2008 \mathrm{H} 1$ \\
\hline & & (in percentage points) & \\
& Group I Banks 1/ & & & \\
Capital adequacy & & & & \\
Regulatory capital to risk-weighted assets & 13.1 & 13.7 & 11.6 & 14.7 \\
Tier I capital to risk-weighted assets & 9.5 & 10.4 & 8.4 & 10.9 \\
Capital to assets 2/ & 6.2 & 6.8 & 5.5 & 5.1 \\
Earnings and profitability & & & & \\
Return on average assets (ROAA) & 1.1 & 1.1 & 0.9 & 0.3 \\
Return on average equity (ROAE) & 22.5 & 22.5 & 18.7 & 7.0 \\
Return on risk-weighted assets (RORWA) & 2.2 & 2.1 & 1.7 & 0.9 \\
Net interest income to total assets & 1.0 & 0.8 & 0.8 & 0.4 \\
Net interest income to gross income & 61.1 & 49.5 & 55.9 & 65.1 \\
Non interest income to gross income & 8.7 & 21.1 & 13.3 & 5.6 \\
Trading income to gross income & 3.4 & 15.5 & 8.1 & -0.4 \\
Fee income to gross income & 29.1 & 26.9 & 28.8 & 27.2 \\
Other income to gross income & 5.3 & 5.6 & 5.2 & 6.0 \\
Non-interest expenses to average assets & 1.0 & 0.9 & 0.9 & 0.5 \\
Non-interest expenses to gross income & 55.0 & 52.4 & 61.1 & 69.3 \\
Personnel expenses to gross income & 54.3 & 51.3 & 57.1 & 59.4 \\
Liquidity & & & & \\
Liquid assets to total assets & 27.0 & 25.0 & 21.0 & 22.0 \\
Deposits to assets & 36.0 & 35.0 & 36.0 & 35.0 \\
Loans-to-deposits & 116.0 & 133.0 & 132.0 & 131.0
\end{tabular}

Group II Banks 1/

Capital adequacy

Tier I capital to risk-weighted assets

Capital to assets $2 /$

Earnings and profitability

Return on average assets (ROAA)

Return on average equity (ROAE)

Return on risk-weighted assets (RORWA)

Net interest income to total assets

Net interest income to gross income

Non interest income to gross income

Trading income to gross income

Fee income to gross income

Other income to gross income

Non-interest expenses to average assets

Non-interest expenses to gross income

Personnel expenses to gross income

Liquidity

$\begin{array}{lllll}\text { Liquid assets to total assets } & 23.0 & 19.0 & 22.0 & 19.0\end{array}$

$\begin{array}{lrrrr}\text { Deposits to assets } & 46.0 & 14.0 & 42.0 & 41.0\end{array}$

Loans-to-deposits

$\begin{array}{rrrr}11.5 & 11.7 & 11.6 & 10.0 \\ 9.8 & 9.4 & 8.8 & 8.1 \\ 9.0 & 9.1 & 9.1 & 7.7 \\ & & & \\ 1.8 & 1.9 & 1.2 & -0.9 \\ 23.2 & 25.4 & 17.0 & -13.3 \\ 2.0 & 2.1 & 1.4 & -1.2 \\ 2.0 & 1.7 & 1.7 & 0.9 \\ 59.3 & 56.0 & 64.2 & 73.6 \\ 15.5 & 20.1 & 9.4 & 0.3 \\ 14.0 & 19.1 & 8.1 & -1.2 \\ 23.9 & 22.9 & 25.6 & 24.1 \\ 1.5 & 1.0 & 1.3 & 1.4 \\ 2.1 & 1.8 & 1.8 & 1.7 \\ 57.3 & 52.4 & 63.1 & 132.4 \\ 52.7 & 52.4 & 58.1 & 62.8 \\ & & & \\ 23.0 & 19.0 & 22.0 & 19.0 \\ 46.0 & 14.0 & 42.0 & 41.0 \\ 121.0 & 138.0 & 141.0 & 146.0\end{array}$

Mortgage Credit Institutions

Capital adequacy

$\begin{array}{lllll}\text { Regulatory capital to risk-weighted assets } & 12.7 & 12.4 & 12.1 & 13.9\end{array}$

$\begin{array}{lllll}\text { Tier I capital to risk-weighted assets } & 11.3 & 11.4 & 11.1 & 13.0\end{array}$

Capital to assets $2 /$

Earnings and profitability

Return on average assets (ROAA)

Return on average equity (ROAE)

Return on risk-weighted assets (RORWA)

Net interest income to total assets

Net interest income to gross income

Non interest income to gross income

Trading income to gross income

Fee income to gross income

Other income to gross income

Non-interest expenses to average assets

Non-interest expenses to gross income

$\begin{array}{rrrr}6.0 & 5.8 & 5.4 & 5.7\end{array}$

Personnel expenses to gross income

$\begin{array}{llll}0.6 & 0.6 & 0.4 & 0.1\end{array}$

$\begin{array}{llll}0.9 & 10.4 & 8.4 & 1.6\end{array}$

$\begin{array}{llll}1.2 & 1.1 & 0.9 & 0.2\end{array}$

$\begin{array}{llll}0.6 & 0.5 & 0.5 & 0.3\end{array}$

$\begin{array}{llll}85.1 & 80.1 & 103.6 & 183.3\end{array}$

$\begin{array}{llll}10.3 & 22.0 & 2.4 & -71.2\end{array}$

$\begin{array}{llll}10.0 & 20.7 & 2.0 & -73.1\end{array}$

$\begin{array}{llll}2.0 & -4.9 & -7.8 & -16.4\end{array}$

$\begin{array}{rrrr}0.4 & 1.3 & 0.3 & 2.0\end{array}$

$\begin{array}{llll}0.2 & 0.2 & 0.2 & 0.1\end{array}$

$\begin{array}{llll}31.1 & 31.0 & 38.6 & 71.0\end{array}$

Source: Danish Financial Supervisory Authority

Notes:

1/ Group I consists of the 5 largest banks; group II consists of the next 11 largest banks by

assets. Taken together, assets held by these banks are 95 percent of banking sector assets.

2/ Shareholders' equity to total assets 
INTERNATIONAL MONETARY FUND

DENMARK

Staff Report for the 2008 Article IV Consultation-Informational Annex

Prepared by the European Department

November 25, 2008

Contents

Page

Appendixes

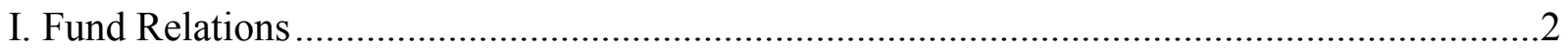

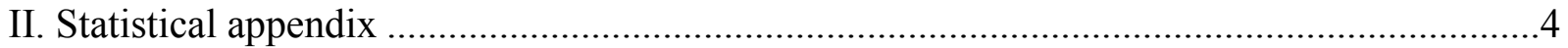




\section{APPENDIX I: DENMARK-FUND RELATIONS}

(As of October 31, 2008)

I. Membership Status: Joined March 30, 1946. Denmark has accepted the obligations of Article VIII.

II. General Resources Account:

Quota

SDR Million

$1,642.80$

$1,525.63$

117.18

Reserve Tranche position

III. SDR Department:

Net cumulative allocation

Holdings
SDR Million
178.86
209.97

Percent Quota
100.00
92.87
7.13

Percent Allocation

100.00

117.39

IV. Outstanding Purchases and Loans: None

V. Financial Arrangements: None

VI. Projected Payments to the Fund: $\underline{2009 \quad 2010} \underline{2011 \quad 2012}$ Principal $\begin{array}{lllll}\text { Charges/Interest } & 0.01 & 0.01 & 0.01 & 0.01\end{array}$ Total $\begin{array}{llll}0.01 & 0.01 & 0.01 & 0.01\end{array}$

VII. Implementation of the HIPC Initiative: Not applicable.

VIII. Implementation of the Multilateral Debt Relief Initiative (MDRI): Not applicable

\section{Exchange Rate Arrangements:}

- $\quad$ Denmark participates in the exchange rate mechanism II (ERMII). It maintains $2 \frac{1}{4}$ percent fluctuation margins vis-à-vis the euro with a central fixed rate at $\mathrm{DKr} 746.038$ per $€ 100$.

- In accordance with UN resolutions and EU restrictive measures, Denmark applies targeted financial sanctions under legislation relating to Al-Qaeda or Taliban, and individuals, groups, and organizations associated with terrorism; certain persons associated with the former Government of Iraq and its state bodies; specific assets of certain persons associated with to important government functions in Myanmar; funds related to military activities in Somalia; funds in relation to Mr. Milosevic and those persons associated with him; funds, other financial assets and economic resources of individual members of the Zimbabwe Government and natural or legal persons associated with them; certain claims by Libya, Liberia, Sudan, Republic of Congo, and the Haitian authorities. These restrictions have been notified to the Fund under Decision $144-(52 / 51)$. 
X. Article IV Consultation: Denmark is on the 24-month consultation cycle. The staff report for the last Article IV consultation (IMF Country Report No. 06/341) was discussed at EBM/06/82 (September 29, 2006).

XI. Technical Assistance: None.

XII. Resident Representative: None. 


\section{Appendix II: Denmark-Statistical Appendix}

Data provision is adequate for surveillance. The country has a full range of statistical publications, many of which are on the Internet. The quality and timeliness of the economic database are generally very good. The country subscribes to the Fund's Special Data Dissemination Standard. Metadata are posted on the Dissemination Standards Bulletin Board.

\section{Monetary and financial statistics}

The authorities have introduced new data on monetary financial institutions that conform to the ESA95 and expanded the set of financial institutions covered in the Nationalbank's statistical bulletin. This permits an examination of some categories of financial institutions not covered before (e.g. money market funds, small banks, and cooperative banks) allowing a more thorough assessment of the financial sector. Some of the financial account data come from this enhanced source. Data for the central bank and other depository corporations are reported to STA on a timely and regular basis. 


\section{DENMARK: TABLE OF COMMON INDICATORS REQUIRED FOR SURVEILLANCE (AS OF NOVEMBER 11, 2008)}

\begin{tabular}{|c|c|c|c|c|c|}
\hline & $\begin{array}{c}\text { Date of } \\
\text { latest } \\
\text { observation }\end{array}$ & $\begin{array}{l}\text { Date } \\
\text { received }\end{array}$ & $\begin{array}{c}\text { Frequency } \\
\text { of } \\
\text { Data }^{7}\end{array}$ & $\begin{array}{l}\text { Frequency } \\
\quad \text { of } \\
\text { Reporting }^{7}\end{array}$ & $\begin{array}{c}\text { Frequency } \\
\text { of } \\
\text { Publication }\end{array}$ \\
\hline Exchange Rates & $10 / 08$ & $11 / 3 / 08$ & $\mathrm{D}$ & $\mathrm{D}$ & $\mathrm{D}$ \\
\hline $\begin{array}{l}\text { International Reserve Assets and Reserve Liabilities } \\
\text { of the Monetary Authorities } 1\end{array}$ & $9 / 08$ & $10 / 31 / 08$ & M & M & M \\
\hline Reserve/Base Money & $8 / 08$ & $10 / 21 / 08$ & M & M & M \\
\hline Broad Money & $8 / 08$ & $10 / 21 / 08$ & M & M & M \\
\hline Central Bank Balance Sheet & $8 / 08$ & $10 / 21 / 08$ & M & M & M \\
\hline Consolidated Balance Sheet of the Banking System & $8 / 08$ & $10 / 21 / 08$ & M & M & M \\
\hline Interest Rates $^{2}$ & $9 / 08$ & $10 / 7 / 08$ & $\mathrm{D}$ & $\mathrm{D}$ & $\mathrm{D}$ \\
\hline Consumer Price Index & $9 / 08$ & $10 / 21 / 08$ & M & M & M \\
\hline $\begin{array}{l}\text { Revenue, Expenditure, Balance and Composition of } \\
\text { Financing }{ }^{3} \text { - General Government }\end{array}$ & Q1 2008 & $8 / 13 / 08$ & A & $\mathrm{A}$ & $\mathrm{A}$ \\
\hline $\begin{array}{l}\text { Revenue, Expenditure, Balance, and Composition of } \\
\text { Financing }{ }^{3} \text { - Central Government }\end{array}$ & 2005 & $4 / 30 / 06$ & A & $\mathrm{A}$ & $\mathrm{A}$ \\
\hline $\begin{array}{l}\text { Stocks of Central Government and Central } \\
\text { Government-Guaranteed Debt }\end{array}$ & 2005 & $4 / 06$ & A & $\mathrm{A}$ & $\mathrm{A}$ \\
\hline External Current Account Balance & Q1 2008 & $7 / 10 / 08$ & M & M & M \\
\hline Exports and Imports of Goods and Services & Q1 2008 & $7 / 10 / 08$ & M & M & M \\
\hline GDP/GNP & Q2 2008 & $10 / 21 / 08$ & Q & Q & Q \\
\hline Gross External Debt & $11 / 05$ & $04 / 06$ & Q & Q & Q \\
\hline International Investment Position ${ }^{6}$ & Q1 2008 & $10 / 23 / 08$ & & & \\
\hline
\end{tabular}

1/ Includes reserve assets pledged or otherwise encumbered as well as net derivative positions.

2/ Both market-based and officially-determined, including discount rates, money market rates, rates on treasury bills, notes and bonds.

3/ Foreign, domestic bank, and domestic nonbank financing.

4/ The general government consists of the central government (budgetary funds, extra budgetary funds, and social security funds) and state and local governments.

5/ Including currency and maturity composition.

6/ Includes external gross financial asset and liability positions vis-à-vis nonresidents.

7/ Daily (D), weekly (W), monthly (M), quarterly (Q), annual (A), irregular (I); and not available (NA) 


\section{Statement by the IMF Staff Representative \\ December 19, 2008}

This statement provides information that became available after the staff report was issued. The thrust of the staff appraisal is unchanged.

\section{Third quarter data suggest lower GDP growth than was assumed in staff's} baseline scenario, implying weaker growth prospects. GDP fell by $1 / 2$ percent in the third quarter of 2008, owing to weak investment and an unexpectedly strong shift to imports. Consequently, staff has marked down growth projections to about zero in both 2008 and 2009, with the output gap now projected to turn negative in 2009 (table).

Table. Denmark. Medium-term Outlook, 2008-11

(Percentage change, unless otherwise indicated)

\begin{tabular}{lrrrr}
\hline & 2008 & 2009 & 2010 & 2011 \\
\hline Real GDP & 0.0 & 0.0 & 0.5 & 1.1 \\
Average unemployment rate & 1.8 & 3.2 & 4.0 & 4.2 \\
General government balance 1/ & 3.0 & 0.0 & -0.9 & -0.6 \\
Output gap 2/ & 0.8 & -0.3 & -0.8 & -0.7 \\
\hline
\end{tabular}

Sources: Danmarks Nationalbank, Statistics Denmark, and IMF staff estimates.

$1 /$ In percent of GDP

2/ In percent of potential output.

2. The authorities have indicated a continued preference for relying primarily on fiscal automatic stabilizers to manage the downturn. Consequently, the structural fiscal balance is broadly unchanged, but the projected slower growth and higher unemployment imply smaller fiscal surpluses in 2008-09 and larger deficits in 2010-11.

\section{Financial markets have calmed but the authorities are considering injecting} capital into banks. Danmarks Nationalbanken matched the ECB's rate cuts in November and December, keeping spreads constant. Interbank rates decreased in November while foreign exchange outflows stopped, and maturing mortgage bonds were rolled over successfully. Against the background of more muted growth prospects, the government is considering ways of increasing the banks' capital buffers, including direct injections of state funds. 


\section{INTERNATIONAL MONETARY FUND}

\section{Public Information Notice}

EXTERNAL

RELATIONS

DEPARTMENT
Public Information Notice (PIN) No. 08/148

FOR IMMEDIATE RELEASE

December 29, 2008
International Monetary Fund $70019^{\text {th }}$ Street, NW

Washington, D. C. 20431 USA

\section{IMF Executive Board Concludes 2008 Article IV Consultation with Denmark}

On December 19, 2008, the Executive Board of the International Monetary Fund (IMF) concluded the Article IV consultation with Denmark. ${ }^{1}$

\section{Background}

The global financial crisis exacerbated a cyclical slowdown that had begun in early 2007, after a long upswing. The slowdown began when Denmark's housing boom ended and residential investment declined. It gained momentum when the financial crisis raised borrowing costs and depressed export growth, consumer confidence, and investment.

The crisis has put financial markets under strain, but most Danish banks, including the half dozen largest, started out with healthy capital buffers which have helped them cope. Direct effects of the crisis were modest because exposures to risky assets were small and because Danish subsidiaries of foreign banks were protected by tight restrictions on intra-group exposures. The main channels of contagion were indirect: increasing risk aversion and a liquidity freeze, which affected all banks, hit small and medium-sized banks particularly hard, leading to a number of mergers and takeovers.

\footnotetext{
${ }^{1}$ Under Article IV of the IMF's Articles of Agreement, the IMF holds bilateral discussions with members, usually every year. A staff team visits the country, collects economic and financial information, and discusses with officials the country's economic developments and policies. On return to headquarters, the staff prepares a report, which forms the basis for discussion by the Executive Board. At the conclusion of the discussion, the Managing Director, as Chairman of the Board, summarizes the views of Executive Directors, and this summary is transmitted to the country's authorities.
} 
The labor market continued tightening after the end of the boom, and unemployment-which began rising only in October 2008-is still close to a historic low. Wage growth picked up in mid2007 and has remained strong, reflecting tight labor market conditions and a generous public sector wage agreement in 2008. Inflation-keeping pace with wage growth-started rising in late 2007, and accelerated to just under 5 percent in mid-2008, with food and energy prices rising rapidly. External competitiveness is adequate, but current trends-faster wage growth and slower productivity growth than in trading partners-are unsustainable.

Denmark's fiscal position is among the strongest in the EU. A gradual reduction in the expenditure ratio, combined with the recent economic boom, led to large surpluses, enabling the government to substantially reduce its debt burden. Consequently, interest spreads on government debt are low.

Economic growth is expected to remain weak through 2010 before recovering gradually. But weaker-than-expected global growth or higher interest rates could drive the economy into a recession.

\section{Executive Board Assessment}

Executive Directors commended the authorities for policies that have enabled Denmark to weather the global crisis well. Nevertheless, conditions remain fragile because of market liquidity constraints and the weakening regional and global outlook, increasing the risk of a severe economic downturn. Directors concurred that the authorities face the combined challenges of steering the economy during a period of substantial growth deceleration; supporting financial stability; and persevering in their decade-long effort to strengthen fiscal sustainability.

Directors considered that the exchange rate peg of the krone to the euro has served Denmark well, anchoring inflationary expectations and keeping interest rates close to those in the euro zone. Macroeconomic policies therefore need to be set in light of Denmark's participation in the European Exchange Rate Mechanism (ERMII). Directors welcomed the authorities' prudent fiscal policy stance, underpinned by a strong rules-based framework, and their readiness to raise interest rates in response to pressures on the peg arising from financial markets' shift in favor of holding risk-free liquid assets.

Directors considered that the proposed 2009 budget strikes a good balance between allowing growth to slow in the face of record low unemployment and rapid wage growth, and cushioning the economy from a severe recession. They viewed the moderate positive fiscal impulse in the budget proposal, added to Denmark's strong automatic stabilizers, as an appropriate response to the increased risk of a hard landing. Directors emphasized that, along with progress on structural reforms, wage growth needs to slow if firms are to rebuild profitability and secure Denmark's competitiveness and export market share.

Directors commended the authorities for their bold response to the financial crisis, and viewed the new liquidity facilities as comprehensive. The proactive and collaborative approach to bank resolution has helped prevent contagion during a period of exceptionally fragile confidence. 
Directors welcomed the new financial stability act, noting that it establishes clear rules and sound incentives for the banking system, helping to secure creditor confidence while safeguarding public resources. The act improves incentives for prudent behavior-including through a temporary dividend moratorium-provides powers to the Danish Financial Supervisory Authority (DFSA) to punish excessive risk-taking, and encourages the private sector to find timely solutions for problem banks. Directors welcomed provisions that level the playing field with respect to cross-border banking operations.

Directors emphasized the importance of intensifying financial sector surveillance and supervision under current financial market conditions. They pointed in this context to potential vulnerabilities stemming from the housing sector and from regional spillovers. Directors welcomed the supervisory authority's initiative to monitor liquidity risk more intensively and comprehensively, and stressed the importance of ensuring that it has the resources to fulfill its expanded mandate under Basel II. They took positive note of the ongoing discussions on a new banking package with the aim of preventing a credit crunch by injecting new capital into the banking sector, subject to adequate safeguards.

Directors noted the impressive achievements of the authorities over the past two decades in reconciling the costs of supportive social safety nets for an aging population with the demands of long-term fiscal sustainability. While recognizing that further progress will involve difficult choices, they encouraged the authorities to take additional measures on both the tax and benefits sides toward closing the long-term fiscal gap.

Directors commended Denmark for maintaining a generously high level of official development assistance, including in the current difficult environment.

Public Information Notices (PINs) form part of the IMF's efforts to promote transparency of the IMF's views and analysis of economic developments and policies. With the consent of the country (or countries) concerned, PINs are issued after Executive Board discussions of Article IV consultations with member countries, of its surveillance of developments at the regional level, of post-program monitoring, and of ex post assessments of member countries with longer-term program engagements. PINs are also issued after Executive Board discussions of general policy matters, unless otherwise decided by the Executive Board in a particular case. The staff report (use the free Adobe Acrobat Reader to view this pdf file) for the 2008 Article IV Consultation with Denmark is also available. 
Denmark: Selected Economic and Social Indicators

\begin{tabular}{|c|c|c|c|c|c|c|}
\hline & 2004 & 2005 & 2006 & 2007 & $\begin{array}{c}2008 \\
\text { proj. }\end{array}$ & $\begin{array}{l}2009 \\
\text { proj. }\end{array}$ \\
\hline \multicolumn{7}{|l|}{ Supply and Demand (change in percent) } \\
\hline Real GDP & 2.3 & 2.4 & 3.3 & 1.6 & 0.0 & 0.0 \\
\hline Net Exports 1/ & -2.0 & -1.1 & -2.1 & -0.3 & -0.8 & 0.0 \\
\hline Domestic demand & 4.1 & 4.3 & 5.1 & 1.6 & 1.3 & 0.0 \\
\hline Private Consumption & 4.7 & 3.8 & 4.4 & 2.4 & 1.8 & 0.8 \\
\hline Gross fixed investment & 3.9 & 4.7 & 13.3 & 3.1 & -0.5 & -3.5 \\
\hline Gross national saving (percent of GDP) & 23.2 & 24.8 & 24.7 & 24.0 & 24.4 & 23.1 \\
\hline Gross domestic investment (percent of GDP) & 20.4 & 20.8 & 22.3 & 22.9 & 22.9 & 22.4 \\
\hline Potential output & 1.3 & 1.8 & 1.8 & 1.3 & 1.2 & 1.1 \\
\hline Output gap (in percent of total output) & -0.5 & 0.1 & 1.6 & 2.0 & 0.8 & -0.3 \\
\hline \multicolumn{7}{|l|}{ Labor Market (change in percent) } \\
\hline Labor force & -0.2 & 0.1 & 1.0 & 0.1 & 0.2 & 0.3 \\
\hline Employment & -0.4 & 0.9 & 2.2 & 1.3 & 1.2 & -1.1 \\
\hline Unemployment rate (in percent) & 5.8 & 5.1 & 3.9 & 2.8 & 1.8 & 3.2 \\
\hline \multicolumn{7}{|l|}{ Prices and Costs (change in percent) } \\
\hline GDP deflator & 2.3 & 2.9 & 2.0 & 2.0 & 4.7 & 2.0 \\
\hline $\mathrm{CPI}$ (year average) & 1.2 & 1.8 & 1.9 & 1.7 & 3.4 & 2.3 \\
\hline Unit labor costs (manufacturing) & -2.9 & -0.4 & 1.6 & 3.1 & 2.4 & 0.6 \\
\hline \multicolumn{7}{|l|}{ Public finance (percent of GDP) 2/ } \\
\hline General government revenues & 56.7 & 58.0 & 56.8 & 55.6 & 53.9 & 51.3 \\
\hline General government expenditure & 54.8 & 53.0 & 51.8 & 51.1 & 50.9 & 51.2 \\
\hline General government balance & 1.9 & 5.0 & 5.0 & 4.5 & 3.0 & 0.0 \\
\hline General government structural balance 3/ & 1.6 & 2.6 & 2.7 & 3.2 & 2.3 & 1.3 \\
\hline General government primary balance & 3.4 & 6.2 & 5.9 & 5.0 & 3.3 & 0.5 \\
\hline General government gross debt & 43.8 & 36.4 & 30.6 & 26.1 & 22.0 & 21.5 \\
\hline \multicolumn{7}{|l|}{ Money and Interest rates (percent) } \\
\hline Domestic credit growth (end of year) & 8.9 & 14.9 & 14.1 & 13.0 & --- & --- \\
\hline M3 growth (end of year) & 2.7 & 14.3 & 11.4 & 17.0 & --- & --- \\
\hline Short-term interest rate ( 3 month) & 2.1 & 2.2 & 3.1 & 4.3 & --- & --- \\
\hline Government bond yield (10 year) & 4.3 & 3.4 & 3.9 & 4.4 & --- & --- \\
\hline \multicolumn{7}{|l|}{ Balance of payments (in percent of GDP) } \\
\hline Exports of goods \& services & 45.4 & 49.0 & 52.0 & 52.3 & 55.4 & 56.6 \\
\hline Imports of goods & 40.5 & 44.1 & 48.9 & 50.2 & 52.9 & 54.8 \\
\hline Trade balance, goods and services & 4.9 & 4.9 & 3.0 & 2.1 & 2.5 & 1.7 \\
\hline Of which: net oil exports (US\$ bln) & 2.6 & 3.2 & 3.8 & 3.8 & 3.8 & 3.8 \\
\hline Current account & 3.1 & 4.4 & 3.0 & 1.1 & 1.5 & 0.8 \\
\hline \multicolumn{7}{|l|}{ Exchange rate } \\
\hline Exchange rate regime & \multicolumn{6}{|c|}{ ERM2 Participant } \\
\hline Average $\mathrm{DKr}$ per US\$ rate & 6.0 & 6.0 & 5.9 & 5.4 & --- & --- \\
\hline Nominal effective rate $(2000=100$, ULC based $)$ & 108.9 & 108.4 & 108.7 & 110.9 & --- & --- \\
\hline Real effective rate $(2000=100$, ULC based $)$ & 113.0 & 112.4 & 113.9 & 119.2 & --- & --- \\
\hline $\begin{array}{l}\text { Social indicators (Reference year) } \\
\text { GDP per capita }(2006) \text { : } \$ 50,818 \text {; At-risk-of-pove }\end{array}$ & & & & & & \\
\hline
\end{tabular}

Sources: IMF, World Economic Outlook; Danmarks Nationalbank; Statistics Denmark; OECD; Eurostat; and IMF staff projections.

$1 /$ Contribution to GDP growth.

2/ Figures for 2008-09 reflect Ministry of Finance estimates and projections as of December 2008; pre-2008 information is from Statistics Denmark.

3/ In percent of potential GDP. 


\section{Statement by Jens Henriksson, Executive Director for Denmark and Katrine Mogensen, Advisor to Executive Director December 19, 2008}

On behalf of our Danish authorities, we would like to thank the staff team for candid and constructive policy discussions in Copenhagen during the Article IV mission. They appreciate the circulated set of high quality papers addressing topical issues for the Danish economy. Our authorities broadly concur with staff's analysis and assessment and will carefully consider the recommendations.

\section{Outlook and Risks}

The outlook for the Danish economy is marked by the financial turmoil and bleak prospects for the global economy. The exchange rate and the interest rate spread vis-à-vis the euro area have been under pressure, confidence indicators have fallen further and public finances are expected to deteriorate amid falling stock and oil prices. In 2010 the fiscal balance is expected to turn clearly negative for the first time since the mid 1990's. However, the structural surplus is expected to remain in positive territory, around 1 percent of GDP in 2009 and 2010.

The recent escalation in the financial turmoil, combined with the gloomy prospects for the international economy, has led to a downward revision of an already weak outlook. Our authorities are now projecting GDP to contract marginally in 2009 and grow moderately in 2010 .

The slowdown in the Danish economy started already at the end of 2006, and the total period of weak growth is expected to last 3-4 years. Weak GDP growth has been accompanied by sturdy growth in domestic demand up until the turn of the year, and employment has risen to a very high level. This development has been reflected in high import growth, a significant fall in productivity and rising unit labor costs, indicating substantial pressures on production capacity. Total demand is now weakening due to the financial turmoil, the slowdown in external demand and the falling house prices. Labor market pressures are, therefore, expected to ease. The expected increase in unemployment tends to dampen wage pressures, but since unemployment also increases abroad, where capacity utilisation is lower, wage competitiveness is still expected to deteriorate.

The outlook is subject to an exceptional degree of uncertainty, reflecting the risks of a prolonged financial turmoil and tightened credit conditions. As stated by staff, risks to the outlook are related to the pressure on the Danish key refinancing rate spread vis-à-vis the euro area, which came into existence during the period of financial turmoil and may give difficulties in reducing interest rates. This could reduce the stimulating effects on demand from the accommodative monetary policy in the euro area. A related risk is the emergence of a credit crunch, where well-functioning, creditworthy households and companies would have trouble getting finance for their activities, which might amplify the adjustment in the housing market. The authorities are aware of the credit constrain problem and have recently agreed on a number of comprehensive initiatives in order to make the interbank markets function, as well as initiatives to support the pension sector and the stable exchange rate policy. The authorities are also considering models for recapitalising banks. The resetting of adjustable rate mortgages in December resulted only in minor increases, thus reducing the related risk of household belt-tightening. 
On the other hand, domestic demand will be supported by economic policy measures. Short term rates are expected to fall to a very low level, which may support the housing market and the financial stability, especially if the financial turmoil is contained. At the same time, fiscal policy is eased due to high growth in public consumption and cuts in personal income taxes. In addition, automatic stabilisers are quite powerful in Denmark.

\section{Fiscal Policies}

Fiscal policy is relatively expansionary in Denmark. The discretionary fiscal expansion (as measured by the direct budgetary impact) is almost 1 percent of GDP in 2009, of which personal income tax cuts and public demand growth each accounts for around one half. Fiscal policy is thus presently more expansionary than in most other EU countries. The first year fiscal impulse to GDP growth of this easing is estimated to 0.4 percent in 2009 (fiscal easing added 0.2 percent to GDP growth in 2008). On the back of the fiscal easing (tax cuts), high wage growth and the significant drop in energy prices since June, households' real disposable income is expected to rise by as much as 33/4 percent in 2009 .

As stated by staff, the economy is still above capacity and unemployment has just started to rise from a very low level, well below the estimated structural unemployment level. Thus, it is important to be cautious in fiscal policy planning since attempts to keep unemployment at its current extraordinary low level will lead to increased imports, a further deterioration of competitiveness, weakening public finances and increased pressure on the interest rate, and may lead to an even higher increase in unemployment than currently projected.

The financial turmoil and the uncertainty about growth outlooks imply that room for manoeuvre at a later stage should be maintained. In Denmark, the starting point is significantly better than in many other countries and there is still some room for manoeuvre due to savings in "good times". It is important that this room is used wisely. Further easing now will reduce, or remove, the fiscal policy options further ahead, when a real need for discretionary fiscal policies might arise.

Public consumption expenditure is expected to rise to 271/4 percent of GDP in 2010, the highest level since 1983 and somewhat above the indicative target of $261 / 2$ percent set in the 2015-plan. This is partly due to the public sector wage agreements of this year. Real public consumption growth is approximately in line with the targets.

To provide against excess spending in municipalities proposals have been adopted to ensure that local government budgets are in line with the tax freeze and the agreements with the government. The proposals imply that the central government block grant to municipalities is reduced if the municipalities on the aggregate exceed the services and investment budget in 2008. In addition, from 2009 onwards the allocation of a part of the block grant to municipalities is depending on whether or not local government budgets are in line with the agreements. Also in the future, local government block grants will be adjusted individually and collectively, if the total taxation in the municipalities exceeds the agreements.

The automatic stabilisers, including automatic changes in tax payments and transfer payments, will dampen the downturn. As stated in the report, the dampening effects from automatic stabilisers are higher in Denmark than in most other countries. Compared to 
discretionary fiscal stimulus, automatic stabilisers have the advantage of being well timed, and do not affect the sustainability of public finances.

The financial turmoil and weaker external demand is expected to lead to a significant weakening of the public finances in the coming years. The surplus is expected to fall from $4 \frac{1}{2}$ to 5 percent of GDP in 2005-07, to 3 percent of GDP this year and around balance next year. In 2010 a deficit of 1.2 percent of GDP is projected.

Periods of financial distress requires fiscal discipline in small economies, like Denmark, with a fixed exchange rate regime outside the euro area. Fiscal policy should support the credibility surrounding the fixed exchange rate regime by ensuring sustainable public finances, and contribute to bring inflation in line with the euro area and a lowering of the interest rate spread vis-à-vis the euro area. Lower interest rates will support the housing market and the financial system, while capacity utilisation normalizes and wage pressures dampen.

\section{Monetary and Exchange Rate Policy}

Our authorities concur with staff's assessment that the exchange rate peg has served Denmark well. The peg to the euro helps anchoring inflation expectations and is thus a cornerstone of the stability oriented economic policy.

In conjunction with the financial crisis in October, Denmark was for the first time in more than 10 years faced with substantial tensions in foreign exchange markets. The unrest was not due to factors in the real economy and shows that when a global financial crisis occurs, a price must be paid for not adopting the euro. At first the pressure on the Danish krone was mainly due to the appearance of a negative spread between our lending rate and the marginal rate of the ECB. Subsequently the intensified financial crisis and a general tendency to move out of smaller currencies also hit Denmark and caused a considerable outflow of capital in a very short time. Danmarks Nationalbank (DNB) responded with a combination of interventions and widening of the interest spread vis-àvis the ECB. From the end of October, the pressure on the krone has eased and DNB has been able to buy back foreign exchange. This has allowed DNB to follow the two latest interest rate reductions of the ECB, announced on November 6 and December 4. Our spread vis-à-vis the ECB currently stands at the somewhat elevated level of 1.75 percent. If the yield spread to the anchor currency is to narrow, further private capital imports are required.

\section{Financial Sector Issues}

Our authorities generally welcome the assessment by staff regarding the Danish responses to the financial crisis.

Staff shows concern about the resources available to the DFSA to recruit and retain appropriate staff in light of their expanded mandate under the Basel II. The budget of an agency such as the DFSA is a matter for the Parliament as part of the annual revision of the Danish National Budget. The resources allocated to the DFSA are increased when the agency is given new assignments. As noted by staff, the authorities increased the DFSA's resources by DKK 10 million as part of the political agreement on financial stability. These resources will be directed at strengthening the work of the DFSA on credit risk in the banking sector. 
The financial crisis and weak international growth outlook has a marked impact on the Danish economy. In the coming years the prospects are associated with greater uncertainty than usually.

A special risk is that a credit crunch can develop, reflecting in particular a need for consolidation in the banking sector and difficulties for many banks to attract new capital. At the same time, there are indications that Danish banks will need extra capital in the near future, as losses mount. If nothing is done, the banks could go on the defensive and cut their activities, thereby reducing the balance-sheet total to meet the capital requirements. In that case, even creditworthy borrowers would find it difficult to obtain financing for sound projects.

The Danish government is prepared to take action in order to reduce that risk. To prevent a credit crunch, a new banking package is currently being discussed, which is to inject new capital into the banking sector. In a situation where banks cannot raise new capital in the markets, many countries have chosen to inject capital into the banking sector by launching government rescue packages in accordance with the conclusion of the European Council summit on October 15 and 16.

Designing a package with the purpose of avoiding a credit crisis is a complex issue. However, a number of principles have to be followed: $i$ ) The aim is only to avoid an actual credit crunch in Denmark; ii) only well-run banks should gain access to temporary financing; and iii) the government should get a return that is as close as possible to a market-based return in proportion to the capital injection made by the state.

\section{Structural Issues}

The Danish economy has been through a long period of significant growth in production and employment and favorable conditions for public finances, both on the revenue side and regarding cyclical expenditures.

The reduction of public debt has been strong during the recent upswing, partly due to high revenues from oil and gas production in the North Sea, pension yield taxation and the corporate tax. The budget surpluses were historical high at 4 $1 / 2-5$ percent of GDP in 20052007 and the expected surplus of around 3 percent of GDP in 2008 is also higher than expected under normal conditions.

As stated by staff future changes in demographics are one of the major challenges facing the Danish economy. In the future the share of elderly people will increase, while at the same time the labor force will shrink. This tends to put pressure on public finances, since revenues from personal income taxes increase less than expenditures on health and retirement pensions. The government has put forward a 2015-plan, including a long term projection and fiscal policy objectives, to prepare for this challenge. The strategy has two tiers; to reduce public debt in times with relatively favorable demographics and high revenues from oil extraction, and to raise labor supply through structural reform.

The key targets in the government's 2015-plan (presented by the government in 2007) are sustainable fiscal policies and surplus on the structural balance all the way towards 2015 . Given the implementation of structural reforms that ensure a rise in unsubsidised employment of 20,000 persons and unchanged average working hours until 2015, the updated 2015-plan in Denmark's Convergence Program 2008, practically fulfils the 
central targets. The estimated structural requirements in order to meet the fiscal targets are to improve public finances by approximately 0.8 percent of GDP. Despite the financial turmoil, this has not changed compared to the 2015-plan (and the Convergence Programme 2007).

A Labor Market Commission has been set up in order to come up with proposals for structural reforms to meet the targets in the 2015-plan. As mentioned in the staff report the Labor Market Commission recently released a number of proposals, including a reduction of the duration of unemployment benefits. The Labor Market Commission is expected to finish its work in the summer of 2009.

A Tax Commission has been established to work out models for a reform of the Danish tax system. The aim of the reform is a notable reduction in labor income taxation, including lower marginal tax rates. The tax reform is expected to help meeting the structural policy requirements in the 2015-plan. The Tax Commission shall present its proposals by early 2009. The tax freeze applies before and after the tax reform.

The selected issues paper provides for interesting analysis, but also shows that quantitative estimates of the financing gaps hinge to a large extent on underlying assumptions. 